\title{
Arsenate impact on the metabolite profile, production, and arsenic loading of xylem sap in cucumbers (Cucumis sativus L.)
}

\author{
M. Kalle Uroic ${ }^{1}$, Pascal Salaün ${ }^{2}$, Andrea Raab ${ }^{1}$ and Jörg Feldmann ${ }^{1}$ * \\ ${ }^{1}$ Trace Element Speciation Laboratory, College of Physical Sciences - Chemistry, University of Aberdeen, Aberdeen, UK \\ ${ }^{2}$ Earth and Ocean Science, University of Liverpool, Liverpool, UK
}

Edited by:

Andrew Meharg, University of

Aberdeen, UK

Reviewed by:

Anne-Marie Carey, University of

Glasgow, UK

Britta Planer-Friedrich, University

Bayreuth, Germany

*Correspondence:

Jörg Feldmann, Trace Element Speciation Laboratory, College of Physical Sciences - Chemistry, Meston Walk, Aberdeen AB24 3UE, UK

e-mail: j.feldmann@abdn.ac.uk
Arsenic uptake and translocation studies on xylem sap focus generally on the concentration and speciation of arsenic in the xylem. Arsenic impact on the xylem sap metabolite profile and its production during short term exposure has not been reported in detail. To investigate this, cucumbers were grown hydroponically and arsenate $\left(\mathrm{As}^{\mathrm{V}}\right)$ and DMA were used for plant treatment for $24 \mathrm{~h}$. Total arsenic and arsenic speciation in xylem sap was analyzed including a metabolite profiling under $\mathrm{As}^{\mathrm{V}}$ stress. Produced xylem sap was quantified and absolute arsenic transported was determined. As ${ }^{\vee}$ exposure had a significant impact on the metabolite profile of xylem sap. Four $\mathrm{m} / \mathrm{z}$ values corresponding to four compounds were up-regulated, one compound down-regulated by $\mathrm{As}^{\vee}$ exposure. The compound down-regulated was identified to be isoleucine. Furthermore, $\mathrm{As}^{\mathrm{V}}$ exposure had a significant influence on sap production, leading to a reduction of up to $96 \%$ sap production when plants were exposed to $1000 \mathrm{gg} \mathrm{kg}^{-1} \mathrm{As}^{\mathrm{V}}$. No difference to control plants was observed when plants were exposed to $1000 \mathrm{\mu g} \mathrm{kg}^{-1}$ DMA. Absolute arsenic amount in xylem sap was the lowest at high $\mathrm{As}^{\vee}$ exposure. These results show that $\mathrm{As}^{\vee}$ has a significant impact on the production and metabolite profile of xylem sap. The physiological importance of isoleucine needs further attention.

Keywords: arsenate, dimethylarsinic acid, isoleucine, metabolite profile, principal component analysis, xylem sap

\section{INTRODUCTION}

Arsenic uptake and translocation in plants and arsenic phytotoxicity have been a focus since the imminent threat of arsenic poisoning in Bangladesh and parts of India (Karim, 2000; Hossain, 2006; Heikens et al., 2007) has been recognized. Millions of people are living on arsenic contaminated ground water and using it for crop irrigation. Rice is the main crop in this region and therefore a widely studied target plant (Meharg and Jardine, 2003; Williams et al., 2005; Xu et al., 2007; Jian et al., 2008; Carey et al., 2010). Arsenic loading into cereals consumed by humans and feedstock is of interest because it is a second arsenic intake pathway for humans after contaminated drinking water (Hossain, 2006).

The uptake and translocation kinetics of arsenic are mainly dependent on its concentration and species (Wang et al., 2002; Ouyang, 2005; Raab et al., 2005). The mechanism for uptake of arsenic in plants is not yet fully understood. But it is assumed, due to chemical similarity, that $\mathrm{As}^{\mathrm{V}}$ is taken up via the same transport system as phosphate (Meharg and Macnair, 1992) whereas $\mathrm{As}^{\mathrm{III}}$ as neutral molecule is transported through aquaglyceroporin channels (Meharg and Jardine, 2003). Plants have evolved a strategy to detoxify arsenic, which is the accumulation of arsenic in the roots by complexing it with phytochelatins (PCs). Subsequently As ${ }^{\mathrm{III}}$ is complexed to PC-As complexes which are thought not to be transported out of the cells and immobilized in the vacuole of the root cells. Phytochelatins are peptides derived from glutathione $(\mathrm{GSH})$ and have the general structure $(\gamma \text {-Glu-Cys })_{n}$-Gly $(n=2-11$; Schmoger et al., 2000) and are found in root cells. These PC-As complexes have been identified in various plants, including Rauvolfia serpentine, $H$. lanatus, P. cretica, Helianthus annuus, and Brassica juncea (Pickering et al., 2000; Schmoger et al., 2000; Raab et al., 2004, 2005).

So far, the As-PCs complexation is the only mechanism known which is responsible for the limitation of inorganic arsenic translocation from roots to shoots (Schmoger et al., 2000; Raab et al., 2004; Liu et al., 2010).

Since arsenic is transported, along with water, macro- and micronutrients, in the xylem sap, sampling it also offers information about arsenic transportation within the plant. Several studies have shown that arsenic transported in xylem sap occurs in several different species, such as $\mathrm{As}^{\mathrm{V}}$, As ${ }^{\mathrm{II}}$, MMA, and DMA (Kertulis et al., 2005; Mihucz et al., 2005; Meirer et al., 2007; Ye et al., 2010; Czech et al., 2011). When inorganic arsenic is fed to plants, inorganic arsenic species are found in xylem. It is plant dependent what ratio of $\mathrm{As}^{\mathrm{III}}$ to $\mathrm{As}^{\mathrm{V}}$ can be found: Plants challenged with methylated species, contain these arsenic species in the sap. It is assumed that $\mathrm{As}{ }^{\mathrm{III}}$ is loaded into the xylem via the Si transporter Lsi2 (Ma et al., 2007). For the loading of $\mathrm{As}^{\mathrm{V}}$ and methylated arsenic species no loading mechanism could be identified until now.

So far, the main focus of research on arsenic impact on plants is on its uptake and detoxification as well as the speciation and concentration of arsenic in xylem sap. No study shows the impact of arsenic on the metabolite profile of xylem sap of plants. Recent 
studies have shown that metabolomics is able to uncover the response of plants on metal stress, such as cadmium on Arabidopsis thaliana (Ducruix et al., 2008) and copper, iron, and manganese on Brassica rapa (Jahangir et al., 2008). However, these studies were performed on whole, homogenized plants.

So far, metabolite profiling in xylem sap was done as targeted analysis in comparing the amount of known substances (i.e., targeted metabolomics), such as amino acids, sugars, or carboxylic acids in stressed plants against control plants (Callahan et al., 2009; López-Millán et al., 2009; Larbi et al., 2010). No untargeted metabolomic study on xylem sap under stress, let alone metal(loid) impact (like $\mathrm{As}^{\mathrm{V}}$ ), on xylem sap was done.

In this work, a study of the impact of $\mathrm{As}^{\mathrm{V}}$ and DMA on the production and metabolite profile of xylem sap in Cucumis sativus L. is presented.

\section{EXPERIMENTAL}

\section{CHEMICALS}

Arsenate $\left(\mathrm{As}^{\mathrm{V}}\right.$, disodium hydrogen heptahydrate) was obtained from BDH Chemicals, Poole, UK. DMA (sodium dimethylarsinic acid) was obtained from Strem Chemicals, UK. Hoagland nutrient solution was made up in double distilled water (DDW). Chemicals were at least of analytical grade $\left[\mathrm{KNO}_{3}, \mathrm{Ca}\left(\mathrm{NO}_{3}\right)_{2} * 4 \mathrm{H}_{2} \mathrm{O}\right.$, $\mathrm{MgSO}_{4}, \mathrm{NH}_{4} \mathrm{NO}_{3}, \mathrm{KH}_{2} \mathrm{PO}_{4}, \mathrm{FeSO}_{4} * 7 \mathrm{H}_{2} \mathrm{O}, \mathrm{MnCl}_{2} * 4 \mathrm{H}_{2} \mathrm{O}$, $\mathrm{Na}_{2} \mathrm{~B}_{4} \mathrm{O}_{7} * 10 \mathrm{H}_{2} \mathrm{O}, \mathrm{ZnSO}_{4} * 7 \mathrm{H}_{2} \mathrm{O}, \mathrm{CuSO}_{4} * 3 \mathrm{H}_{2} \mathrm{O}, \mathrm{Na}_{2} \mathrm{MoO}_{4}$ $* 2 \mathrm{H}_{2} \mathrm{O}$ (all from Sigma Aldrich, Dorset, UK)].

\section{PLANT GROWTH}

Cucumber seeds (C. sativus L. Telegraph improved, B\&Q, Aberdeen) were germinated in seedling trays in Vermiculite ${ }^{\circledR}$ until their two leaf stage, which took approx. 1 week. Reaching that, four plants each were transferred into one $3 \mathrm{~L}$ pot containing hydroponic nutrient solution [Hoagland solution: $2.5 \mathrm{mM} \mathrm{KNO}_{3}$, $2.5 \mathrm{mM} \mathrm{Ca}\left(\mathrm{NO}_{3}\right)_{2}, 1.0 \mathrm{mM} \mathrm{MgSO}_{4}, 0.5 \mathrm{mM} \mathrm{NH}_{4} \mathrm{NO}_{3}, 0.5 \mathrm{mM}$ $\mathrm{KH}_{2} \mathrm{PO}_{4}$ (adjusted to $\mathrm{pH} 6.3$ ), $0.05 \mathrm{mM} \mathrm{FeSO}_{4}, 4.5 \mu \mathrm{M} \mathrm{MnCl}_{2}$, $50 \mu \mathrm{M} \mathrm{Na} \mathrm{B}_{4} \mathrm{O}_{7}, 0.36 \mu \mathrm{M} \mathrm{ZnSO}, 0.36 \mu \mathrm{M} \mathrm{CuSO}_{4}, 0.25 \mu \mathrm{M}$ $\mathrm{Na}_{2} \mathrm{MoO}_{4}$ ]. For the first week, half-strength, for the rest of the time full-strength nutrient solution was used. Three different plant batches were grown. Plant set B was grown until before developing flowers and blooming (flowering stage); plant sets $\mathrm{A}$ and $\mathrm{C}$ were grown until blooming (flowering stage). A pot with four plants each was used as replicate for the challenge experiments.

\section{Plant set A}

Three sets of plants grown for $28 \pm 3$ days (flowering stage).

(a) Three pots of four plants each were challenged with no arsenic (12 plants in total).

(b) Three pots of four plants each were challenged with $710 \mu \mathrm{g} \mathrm{kg}^{-1} \mathrm{As}^{\mathrm{V}}$ (12 plants in total) for $24 \mathrm{~h}$.

(c) Three pots of four plants each were challenged with $1400 \mu \mathrm{g} \mathrm{kg}^{-1} \mathrm{As}^{\mathrm{V}}$ (12 plants in total) for $24 \mathrm{~h}$.

In total, 36 plants were used in plant set $\mathrm{A}$.

\section{Plant set B}

Five sets of plants grown for $26 \pm 3$ days (before flowering stage). Each set was grown in a separate batch. Four plants each were challenged with 100, 500, and $1000 \mu \mathrm{g} \mathrm{kg}^{-1} \mathrm{As}^{\mathrm{V}}$ each, $1000 \mu \mathrm{g} \mathrm{kg}^{-1}$ DMA, and no arsenic (20 plants in total) for $24 \mathrm{~h}$.

\section{Plant set C}

Five sets of plants with four plants each were grown for $48 \pm 4$ days (flowering stage). Four plants each were challenged with 100, 500, and $1000 \mu \mathrm{g} \mathrm{kg}^{-1} \mathrm{As}^{\mathrm{V}}$ each, $1000 \mu \mathrm{g} \mathrm{kg}^{-1} \mathrm{DMA}$, and no arsenic (20 plants in total) for $24 \mathrm{~h}$.

All plants were grown in a greenhouse at adjusted temperature $\left(26 \pm 2^{\circ} \mathrm{C}\right)$. Humidity was not adjusted since temperature control was done by opening the windows and a heating system.

For set B artificial light was used to ensure a 12-h light period.

\section{PLANT TREATMENT AND SAP SAMPLING}

All plants were starved on phosphate with phosphate-free Hoaglands solution for the last 2 days of growth before arsenic treatment. Four plants each were exposed to either DMA and As $\mathrm{V}$ at different concentrations ( 700 and $1400 \mu \mathrm{g} \mathrm{kg}^{-1} \mathrm{of} \mathrm{As}^{\mathrm{V}}$ for plant set $\mathrm{A}$ and 100,500 , and $1000 \mu \mathrm{g} \mathrm{kg}^{-1}$ for $\mathrm{As}^{\mathrm{V}}$ and $1000 \mu \mathrm{g} \mathrm{kg}^{-1}$ for DMA or no arsenic for plant sets B and C, respectively). Plant treatment always lasted $24 \mathrm{~h}$ before sampling.

After $24 \mathrm{~h}$ all stems were cut approx. $1 \mathrm{~cm}$ above their root neck, the first drop was wiped away and sap was collected with a micropipette for $1 \mathrm{~h}$. Sap samples were weighed and then either measured right after extraction or stored at $-20^{\circ} \mathrm{C}$ until further analysis. The sap was analyzed by ESI-MS for sucrose in order to test whether the xylem was contaminated with phloem.

\section{QUANTIFICATION AND SPECIATION OF ARSENIC IN SAP}

Sap collected from exudation was centrifuged and either diluted with ultrapure water to make up to $500 \mu \mathrm{L}$ or injected directly into HPLC-ICP-MS (Agilent 1100 HPLC coupled to Agilent 7500c ICP-MS). External calibration was achieved by injection of DMA standard solution ranging from 0.5 to $100 \mu \mathrm{g} \mathrm{kg}^{-1}$.

To detect chloride interferences, $m / z$ values 77 and 82 were also monitored. Indium $\left(50 \mu \mathrm{g} \mathrm{kg}^{-1}\right)$ was infused continuously post column via a peristaltic pump as internal standard.

\section{MEASUREMENT OF THE METABOLITE PROFILE OF XYLEM SAP}

The metabolite profile was determined using plant set A. For separation a reversed-phase column (C18, Eclipse XDB-C18, Agilent, Agilent USA) was used. Hundred microliter of the sample was injected using a $0.1 \%$ formic acid in water $-0.1 \%$ formic acid in methanol gradient with $1 \mathrm{~mL} \mathrm{~min}^{-1}$ flow. Starting from $100 \%$ water, methanol was added to the eluent after $5 \mathrm{~min}$. From 5 to $25 \mathrm{~min}$ the methanol fraction was increased to $100 \%$. The eluent was held at $100 \%$ methanol for a further $5 \mathrm{~min}$, followed by re-equilibration. Total chromatographic run time was $40 \mathrm{~min}$. The eluent flow was injected into an ESI-MS (MSD XCT, Agilent USA). The ESI-MS was used in positive/negative switch mode and MS ${ }^{2}$ spectra were recorded when signal intensities were higher than 50,000 counts.

\section{STATISTICAL ANALYSIS}

The variation in xylem sap production, arsenic amount, and the intensities for the selected metabolites was determined by $t$-test with SigmaPlot 11. Multiple linear regressions were done with Minitab 15. 
All chromatograms obtained by RP-HPLC-ESI-MS after sap analysis in positive mode were converted into bins (bin size $1 \mathrm{~m} / z$ and $1 \mathrm{~min}$ ) with ProfileAnalysis 1.0 (Bruker). These bins were imported into PyChem $3.05 \mathrm{~g}$ (Jarvis et al., 2006) for PCA. Briefly, chromatograms obtained by the Agilent MSD XCT system were preprocessed by ProfileAnalysis into a matrix in which each column represents a sample and each row $1 \mathrm{~m} / \mathrm{z} /$ time bin. The specifications were $1 \mathrm{~min}$ time and $1 \mathrm{~m} / z$ mass per bin. The range was defined from 0 to $35 \mathrm{~min}$ and from 80 to $1000 \mathrm{~m} / z$. An average of all intensities in each bin was used. ProfileAnalysis created a matrix with 32,810 bins (rows) and 32 samples (columns) which have a total of 1,049,920 data points. The matrix was exported as ASCII file and used for PCA analysis with the statistical software package PyChem. In PyChem, no data pretreatment was performed. PCA was done on raw spectra by calculating 10 principal components (PC).

\section{IDENTIFICATION OF XYLEM CONSTITUENTS}

Separation was performed on a $\mathrm{C}_{18}$ reverse-phase column $(\mathrm{C} 18$, Eclipse XDB-C18, Agilent, Agilent USA), using a $0.1 \%$ formic acid in water $-0.1 \%$ formic acid in methanol gradient with $1 \mathrm{~mL} / \mathrm{min}$ flow. Starting from $100 \%$ water, methanol was added to the eluent after $7 \mathrm{~min}$. From 7 to $25 \mathrm{~min}$ the methanol fraction was increased to $100 \%$. The eluent was held at $100 \%$ methanol for a further $5 \mathrm{~min}$, followed by re-equilibration of the column. Total chromatographic run time was $40 \mathrm{~min}$. Hundred microliter of the sample was used. The eluent flow was injected into a high resolution ESIMS (LTQ Orbitrap Discovery; Thermo Fisher Scientific) with a resolution of 30,000. Accurate masses of selected $\mathrm{m} / z$ values were used for chemical formula generation with X-calibur 2.0 (Thermo Fisher Scientific).

\section{RESULTS}

\section{ARSENATE IMPACT ON THE METABOLITE PROFILE OF XYLEM SAP}

Xylem sap collected from plant set A was used for determination of the metabolite profile. One plant of the 12 challenged with $710 \mu \mathrm{g} \mathrm{kg}^{-1} \mathrm{As}^{\mathrm{V}}$ and 3 plants of the 12 challenged with $1400 \mu \mathrm{g} \mathrm{kg}^{-1} \mathrm{As}^{\mathrm{V}}$ did not produce enough sap for analysis, therefore 32 instead of 36 samples were measured with RP-HPLC-ESIMS. Total ion chromatograms of all 32 sap samples are shown in Figure A1 in appendix. The chromatograms have a good retention time alignment, as can be seen at the peaks of the positive mode chromatograms at $\sim 10.5$ and $23 \mathrm{~min}$, respectively. This enables PCA without further peak alignment of the metabolite profile of the xylem sap. PC1 and PC2 combined explain $86 \%$ of the variation [PC1 (76\% of variation) vs PC2 (10\% of variation)], therefore only these two PCs were used for further analysis.

The PCA scores plot (Figure A2 in appendix) indicates that there is a separation of xylem sap sampled from plants challenged with $\mathrm{As}^{\mathrm{V}}$ and without challenge. However, in order to assess the statistical significance, a cluster observation was done (see Figure A3 in appendix). The samples in the PCA scores plot are color coded according to their clustering in the dendrogram, showing that 8 of the $710 \mu \mathrm{g} \mathrm{kg}^{-1}$ and 1 of the $1400 \mu \mathrm{g} \mathrm{kg}^{-1}$ samples are clustered together with the unchallenged plants whereas 4 of the $710 \mu \mathrm{g} \mathrm{kg}^{-1}$ challenged plants are clustered with the remaining $1400 \mu \mathrm{g} \mathrm{kg}^{-1}$ challenged samples.
This separation of the $710 \mu \mathrm{g} \mathrm{kg}^{-1}$ samples is also visible in the sap flow results. The three $710 \mu \mathrm{g} \mathrm{kg}^{-1}$ samples in the group with the $1400 \mu \mathrm{g} \mathrm{kg}^{-1}$ samples are from one pot where all four samples exuded little xylem sap during extraction which indicates high impact of $\mathrm{As}^{\mathrm{V}}$ stress (see Figure $\mathrm{A} 4$ in appendix). The other eight $710 \mu \mathrm{g} \mathrm{kg}^{-1}$ samples were from plants exuding amounts of sap similar to the control plants showing low $\mathrm{As}^{\mathrm{V}}$ impact. This however could be the effect of the reduced sap flow and simply a concentration effect. Therefore individual metabolites need to be studied. This is achieved by analyzing the PCA loading plot. This plot shows which bins $(\mathrm{m} / z$ values at respective retention time) are responsible for the clustering in the scores plot; in this case which $\mathrm{m} / \mathrm{z}$ value at what retention time. The loadings plot (Figure A5 in appendix) reveals that the $\mathrm{m} / z$ values of $132,203,219,253$, and 312 are significantly different within the 32 samples. For verification purpose all chromatographic peaks resulting from these $\mathrm{m} / z$ values in all chromatograms were integrated. The obtained peak areas were used for testing the statistical significance between each condition group. Furthermore, peak areas of a random $\mathrm{m} / \mathrm{z}$ value which was not identified in the PCA loadings plot were also integrated $(\mathrm{m} / z$ 233). This was done to assess if the decreased sap flow, as discussed before, has a major influence. This random value $(m / z 233)$ was chosen because its peak area was within the peak area and retention time range of the other, significantly different peaks. Figure 1 shows box plots of peak areas of all $\mathrm{m} / z$ values of all three conditions.

The plot shows that $m / z 132$ is down-regulated with increased $\mathrm{As}^{\mathrm{V}}$ exposure while $m / z 219,253,312$, and 203 are up-regulated. There is no significant difference between control and challenged plants with $m / z 233$. All box plots of the $m / z$ values of 132, 219, 253,312 , and 203 show that there is always a statistical significant difference with $P<0.01$ between the control and $1400 \mu \mathrm{g} \mathrm{kg}^{-1}$ samples and with one exception also between the control and the $710 \mu \mathrm{g} \mathrm{kg}^{-1}$ samples. The exception is at $m / z 253$, which has no significant difference between control and $710 \mu \mathrm{g} \mathrm{kg}^{-1}$ samples. There is no statistical difference between both the control and the $710 \mu \mathrm{g} \mathrm{kg}^{-1}$ samples and control and the $1400 \mu \mathrm{g} \mathrm{kg}^{-1}$ samples at $m / z 233$, which shows that the reduced sap flow is not the reason for the statistical significance of the other $\mathrm{m} / z$ values. With the peak areas of $m / z 132,219,253,312$, and 203 and the results for sap flow and total arsenic concentration, multiple linear regressions were done. The $\mathrm{m} / z$ values of 132,312 , and 203 have a significant influence on the result, with $P<0.05(0.022,0.002$, and $<0.001$, respectively), while for $\mathrm{m} / z 219$ and 253 the $P$-values were $>0.05$ ( 0.791 and 0.726 , respectively). Hence, the following equation can be used to calculate the total arsenic concentration in xylem sap from the amount of the three bio-molecules:

$$
\begin{aligned}
c_{\text {model }}\left(\mathrm{As}_{\mathrm{sap}}\right)= & 10.502-(0.0000946 * \mathrm{~m} / \mathrm{z} 132) \\
& -(0.000410 * \mathrm{~m} / z 312)+(0.00202 * \mathrm{~m} / z 203)
\end{aligned}
$$

Plotting the modeled As concentration of this equation vs the actual measured concentration (see Figure 2A) shows that the resulting curve has a good correlation $\left(R^{2}=0.71\right)$ considering the biological variability.

Furthermore, multiple linear regressions were used to assess possible biomarkers for sap flow, using the peak areas of $m / z 132$, 

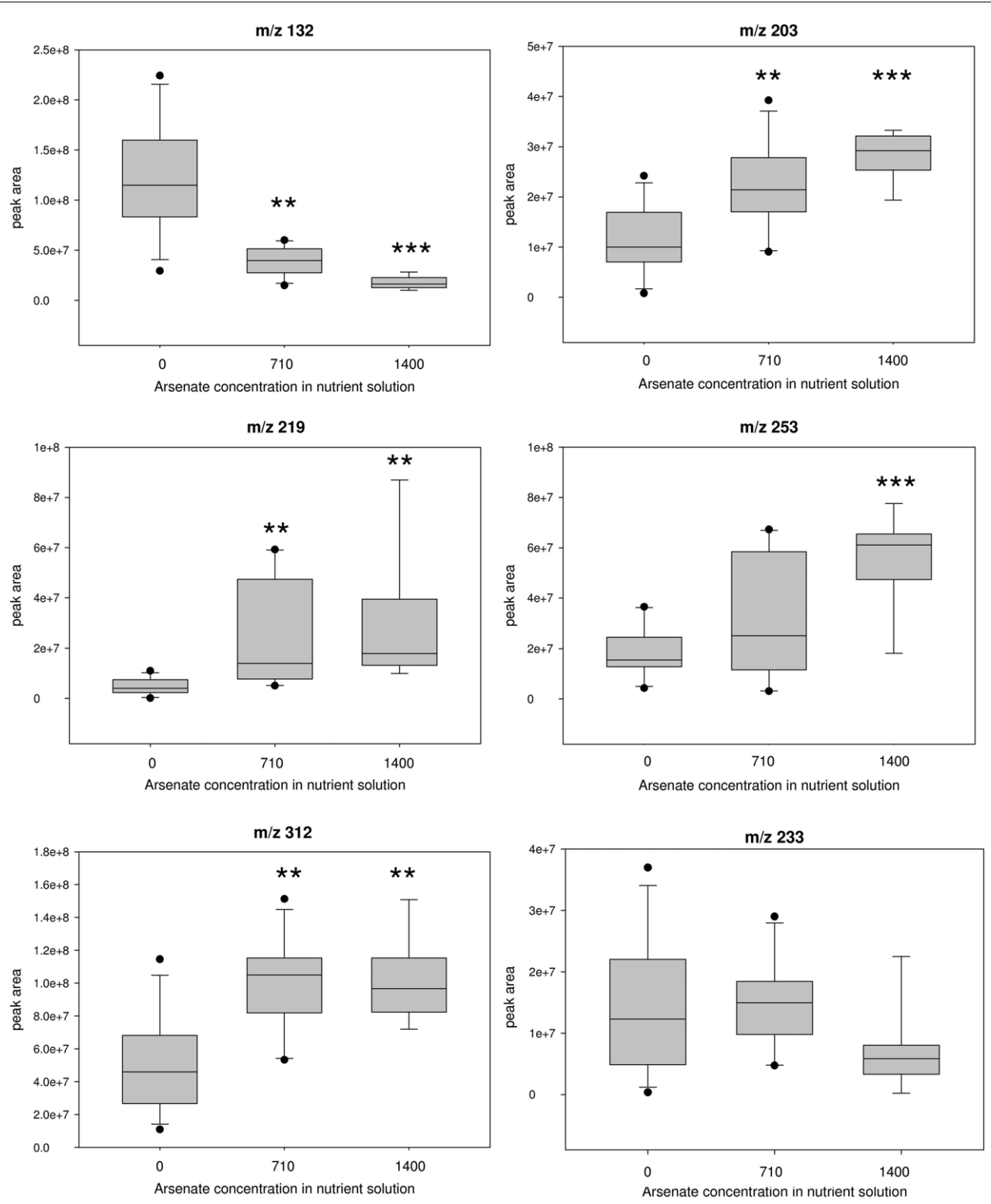

FIGURE 1 | Box plots of peak areas of peaks of $\mathrm{m} / \mathrm{z}$ values 132 ,

219, 253, 312, 203, and 233. Peak areas were obtained from

arsenic, 710 and $1400 \mu \mathrm{g} \mathrm{kg}^{-1}$ arsenate. Statistical significance according to: $P>0.05(\mathrm{~ns}),{ }^{*} P=0.01-0.05,{ }^{*} P=0.001-0.01$, ***P $P 0.001(n=12)$.

$219,253,312$, and 203 and the sap flow. In this case, only $\mathrm{m} / z 253$ and 203 have a significant influence on the result, or a $P$-value $\leq 0.05$ which leads to the following equation (see Figure $2 B$ ):

Sap flow $=3.464-\left(0.0000218^{\star} m / z 253\right)-\left(0.0000851^{\star} m / z 203\right)$

The results show that $m / z 203$ and 253 could be used as possible biomarkers for sap flow under arsenic stress.

\section{Identification of significant $\mathrm{m} / \mathrm{z}$ values}

Xylem sap was measured with the LTQ Orbitrap Discovery system to identify the compounds found in experiment A).

For the determination of $\mathrm{m} / z$ 132, xylem sap of control plants was injected since this compound is down-regulated under arsenic stress and is most abundant in xylem sap of control plants. The extracted ion chromatogram shows a distinct peak at $4.5 \mathrm{~min}$ (Figure A6 in appendix). The accurate MS for this peak and the fragments of the $\mathrm{MS}^{2}$ are presented in Figure A7 in appendix and a possible chemical formula is shown in Table A1 in appendix. For the determination of the other $4 \mathrm{~m} / z$ species $(203,219$, 253 , and 312) xylem sap of plants challenged with $\sim 1400 \mu \mathrm{g} \mathrm{kg}^{-1}$ $\mathrm{As}^{\mathrm{V}}$ for $24 \mathrm{~h}$ was used (Figure $\mathbf{A 8}$ in appendix). All $\mathrm{m} / z$ ranges (species $\pm 0.5 \mathrm{~m} / z$ ) resulted in one peak each (chromatograms can be found in the supplement information as well as MS and $\mathrm{MS}^{2}$ spectra; Figures A8-A12). The accurate MS data for the base peak and proposed chemical formulae are presented in Table 1. 
These formulae were then used to search for known natural products in a database ${ }^{1}$. Only $m / z 132$ was unequivocally identified as isoleucine.

A spiking experiment with isoleucine standard showed that the unknown peak is increasing with added isoleucine (Figure A13 in appendix). Furthermore, the $\mathrm{MS}^{2}$ of this $\mathrm{m} / z$ value is also matching. The co-elution, matching accurate mass for $[\mathrm{M}-\mathrm{H}]^{+}$

${ }^{1}$ Dictionary of Natural Products on DVD, ver. 19.1, Taylor \& Francis Group, 2010.
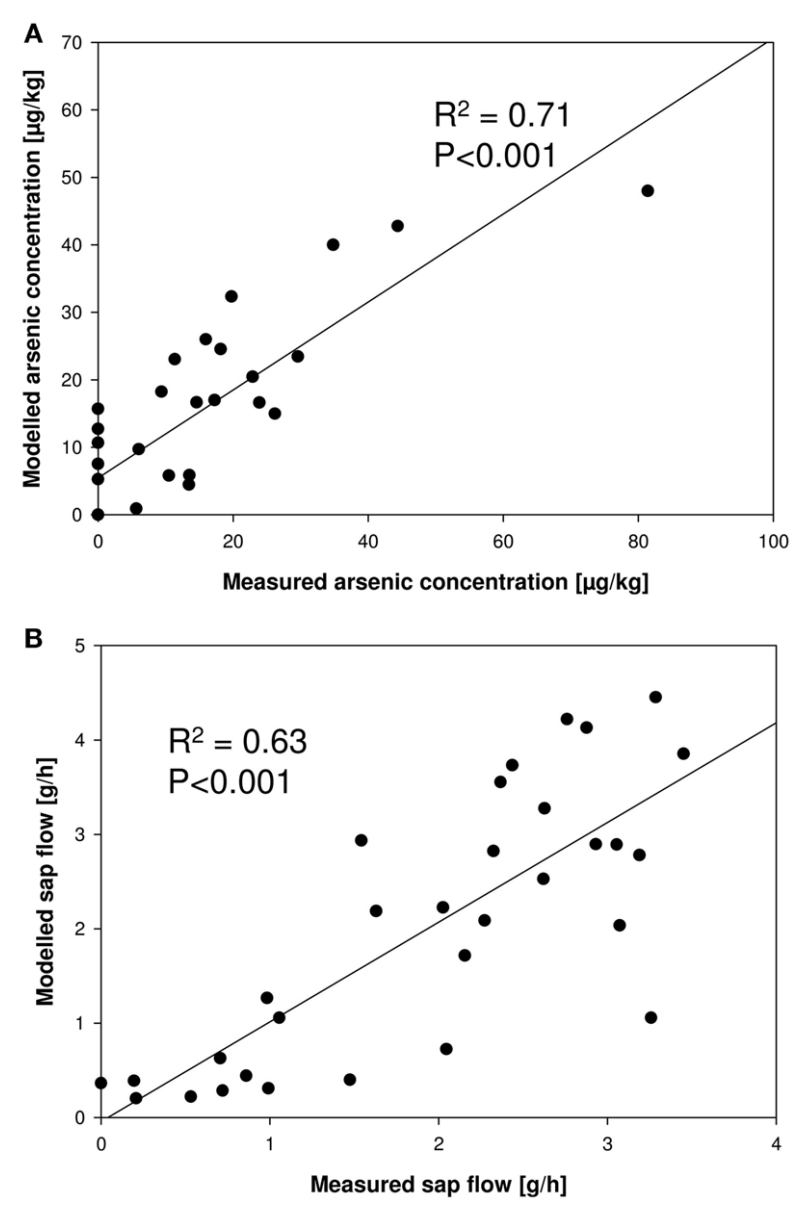

FIGURE 2 | Plot of modeled arsenic concentration in sap vs measured arsenic concentration in sap (A) and modeled sap flow calculated by multiple linear regression vs measured sap flow (B).

Table 1 | Accurate mass determination for all five significant species in xylem sap after arsenate challenge.

\begin{tabular}{llll}
\hline Species & $\begin{array}{l}\text { Accurate } \\
\text { mass }\left[\mathbf{M}-\mathbf{H}^{+}\right]\end{array}$ & $\begin{array}{l}\text { Retention } \\
\text { time [min] }\end{array}$ & $\begin{array}{l}\text { Proposed chemical formulae } \\
\text { and measured error ( } \mathbf{\Delta p p m )}\end{array}$ \\
\hline 132 & 132.1018 & 4.5 & $\mathrm{C}_{6} \mathrm{H}_{14} \mathrm{NO}_{2}(-0.872)$ \\
203 & 203.1390 & 3.4 & $\mathrm{C}_{7} \mathrm{H}_{17} \mathrm{~N}_{5} \mathrm{O}_{2}(+3.267)$ \\
219 & 219.0970 & 2.4 & $\mathrm{C}_{8} \mathrm{H}_{15} \mathrm{~N}_{2} \mathrm{O}_{5}(-2.136)$ \\
253 & 253.1180 & 11.6 & $\mathrm{C}_{12} \mathrm{H}_{17} \mathrm{~N}_{2} \mathrm{O}_{4}(+3.434)$ \\
312 & 312.1286 & 4.6 & $\mathrm{C}_{11} \mathrm{H}_{22} \mathrm{NO}_{9}(-1.658)$
\end{tabular}

(see Figure A14 for MS and $\mathrm{MS}^{2}$ of isoleucine) and the matching $\mathrm{MS}^{2}$ are robust proof that the unknown compound at $\mathrm{m} / \mathrm{z}$ 132 is isoleucine, which is down-regulated under $\mathrm{As}^{\mathrm{V}}$ stress in cucumbers.

\section{IMPACT OF ARSENIC STRESS ON SAP FLOW}

Plants of set (A) challenged with increasing $A s^{V}$ concentration showed reduced sap flow. This was further investigated with two experiments (plant set $\mathrm{B}$ and $\mathrm{C}$ ) which differ in age (before flowering and during flowering) using the same $\mathrm{As}^{\mathrm{V}}$ and DMA concentrations. Xylem sap was collected for $1 \mathrm{~h}$ after decapitation of each plant. Sap extracted by exudation was clear and without color. Figure 3 shows sap flows of plant set B and C after challenge with $\mathrm{As}^{\mathrm{V}}$ at 100,500 , and $1000 \mu \mathrm{g} \mathrm{kg}^{-1}$ and DMA at $1000 \mu \mathrm{g} \mathrm{kg}^{-1}$, respectively compared to sap flow of unchallenged plants.

The plants of set B (challenged before flowering) showed significantly lower sap flow than those of plant set C (challenged
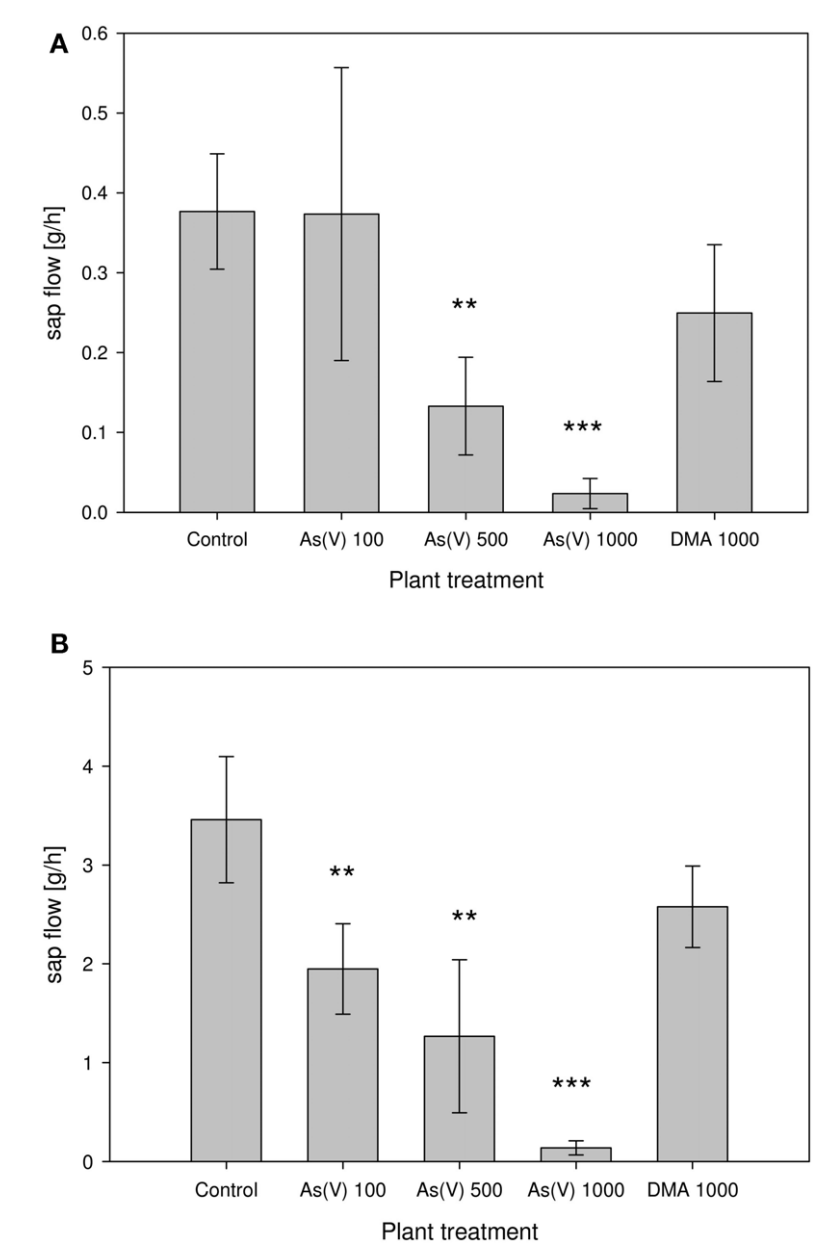

FIGURE 3 | Sap flow of decapitated cucumbers of plant set B (Figure $3 A$ ) and $C$ (Figure $3 B$ ) after challenge of plants with $A s^{v}$ at 100, 500, and $1000 \mu \mathbf{g ~ k g - 1}$ and DMA at $1000 \mu \mathbf{g ~ k g}^{-1}$ for $24 \mathrm{~h}$. Sap was collected for $1 \mathrm{~h}$. Statistical significance against control is indicated by asterisks if applicable according to: ${ }^{*} P=0.01-0.05,{ }^{*} P=0.001-0.01$ *** $P<0.001$ ( $t$-test; $n=4$ ). 
during flowering). Unchallenged plants produce the highest sap flow within one set of plants. Plants challenged with $\mathrm{As}^{\mathrm{V}}$ show a significant decrease in sap flow with increased arsenic concentration. This accounts both for plants which have reached flowering stage and before reaching flowering stage. High $\mathrm{As}^{\mathrm{V}}$ challenge of $1000 \mu \mathrm{g} \mathrm{kg}^{-1} \mathrm{As}^{\mathrm{V}}$ in the nutrient solution leads to $96 \%$ reduction of xylem sap production. Plants challenged with DMA show no significant change in sap production.

In order to assess a correlation between inorganic arsenic stress (i.e., inorganic arsenic concentration in nutrient solution) and sap flow, arsenic concentration was determined in all nutrient solutions prior to plant challenge. Figure 4 shows sap flow of cucumber plants subjected to $\mathrm{As}^{\mathrm{V}}$ with sap flow of control plants set to $100 \%$. In contrast to the graphs the sap flow is plotted against the measured $\mathrm{As}^{\mathrm{V}}$ concentration in the nutrient solution prior to plant treatment. Both slopes show a linear correlation, with $R^{2}$ of 0.98 for set $\mathrm{B}$ and 0.89 for set $\mathrm{C}$. The slope of both graphs is similar and not significantly different, when normalized to control plants. Hence, the combined slope is -8.8 with an $R^{2}$ of 0.89 $(P<0.001)$.

The graph shows that although the absolute sap flow is differing by a factor of $8-10$ between the two sets, the relative sap flow reduction is similar in both plant sets. The impact of $\mathrm{As}^{\mathrm{V}}$ on the sap flow is independent of the plants developmental stage.

This is the first time that a linear correlation is observed between the arsenic concentration plants are subjected to and the sap flow.

\section{ARSENIC CONCENTRATION AND SPECIATION IN XYLEM SAP}

Sap samples extracted from plants grown hydroponically and extracted via exudation were injected for arsenic determination and speciation into anion-exchange HPLC-ICP-MS. Chromatograms of xylem sap of plant set $\mathrm{B}$ and $\mathrm{C}$ can be found in the supplement information and show only the occurrence of DMA and the inorganic arsenic species (Figures A15 and A16 in appendices). Table 2 shows the concentration of those arsenic species found in xylem sap after arsenic challenge with $\mathrm{As}^{\mathrm{V}}$ and DMA, respectively.

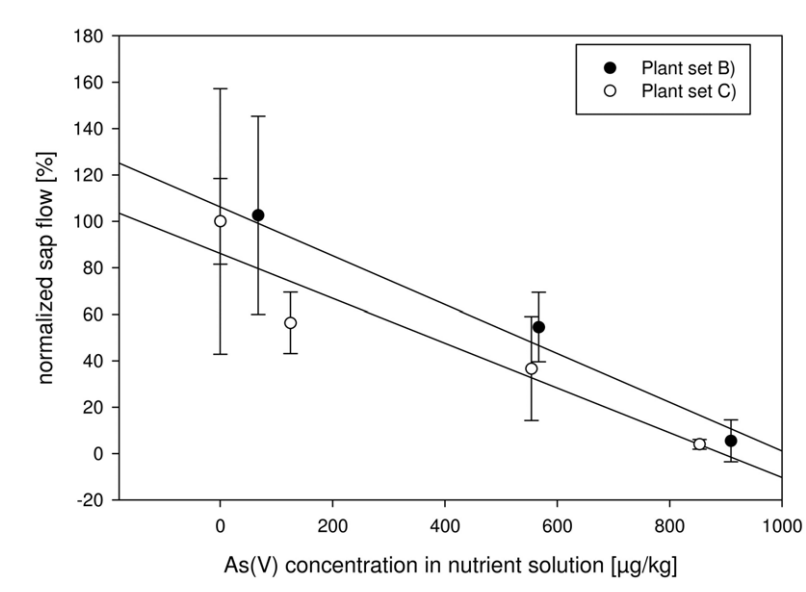

FIGURE 4 | Xylem sap flow normalized against sap of control plants flow vs arsenate concentration in nutrient solution before challenge. Sap flow of control plants set to $100 \%$.
When plants were challenged with DMA, they transported only DMA in the sap, no other species was detected. When plants were exposed to $100 \mu \mathrm{g} \mathrm{kg}^{-1} \mathrm{As}^{\mathrm{V}}$, both inorganic arsenic species appeared in the xylem sap of older plants. As ${ }^{\mathrm{III}}, \mathrm{As}^{\mathrm{V}}$, and MMA were found when plants were exposed to MMA with MMA being the main fraction (Ye et al., 2010).

The main difference between younger plants and plants in the flowering stage is the increased $\mathrm{As}^{\mathrm{V}}$ and $\mathrm{As}{ }^{\mathrm{III}}$ concentration in xylem sap of older plants. Younger plants seem to be able to control the xylem loading of $\mathrm{As}^{\mathrm{V}}$. At 500 and $1000 \mu \mathrm{g} \mathrm{kg}^{-1}$ exposure to $\mathrm{As}^{\mathrm{V}}$ only $\mathrm{As}^{\mathrm{III}}$ was detected in the sap, leading to the assumption that all $\mathrm{As}^{\mathrm{V}}$ was reduced to $\mathrm{As}{ }^{\mathrm{III}}$ in roots before xylem sap loading.

Arsenic speciation and concentration as well as arsenic amount in plant set A show a main fraction of As ${ }^{\mathrm{III}}$ with a smaller fraction of $\mathrm{As}^{\mathrm{V}}$. DMA ${ }^{\mathrm{V}}$ was detected in traces (see Figure $\mathrm{A} 17$ in appendix).

\section{IMPACT OF ARSENIC STRESS ON ABSOLUTE AMOUNT OF ARSENIC TRANSPORTED IN XYLEM SAP}

In order to calculate the absolute amount of arsenic transported in $1 \mathrm{~h}$ the sap flow is multiplied with the total arsenic concentration. The following equation was used:

$$
\begin{aligned}
\text { Arsenic transported }\left[\mathrm{ng} \mathrm{h}^{-1}\right]= & \text { Sap flow }\left[\mathrm{g} \mathrm{h}^{-1}\right] \\
& \times \text { Arsenic concentration }\left[\mathrm{ng} \mathrm{g}^{-1}\right]
\end{aligned}
$$

With this formula the actual amount of arsenic transported in the xylem within $1 \mathrm{~h}$ is calculated.

Figure 5 shows the amount of arsenic in sap samples of plant set $B$ and $C$. When plants are challenged with $1000 \mu \mathrm{g} \mathrm{kg}^{-1} \mathrm{DMA}$, the total arsenic amount is highest in both plant sets. In contrast, the amount of arsenic transported is significantly smaller when plants are subjected to $1000 \mu \mathrm{g} \mathrm{kg}^{-1} \mathrm{As}^{\mathrm{V}}$.

In younger plants (plant set B), the amount of total arsenic in xylem sap is significantly reduced with increasing $\mathrm{As}^{\mathrm{V}}$ concentration in the nutrient solution.

Older plants (plant set C) show a different pattern, with the plants challenged with $\sim 500 \mu \mathrm{g} \mathrm{kg}^{-1} \mathrm{As}^{\mathrm{V}}$ having the highest arsenic amount with $46 \pm 30 \mathrm{ng} \mathrm{h}^{-1}$. Arsenic amounts of plants challenged with $\sim 100$ and $\sim 1000 \mu \mathrm{g} \mathrm{kg}^{-1}$ are lower, with $5.6 \pm 1.4$ and $14.0 \pm 1.7 \mathrm{ng} \mathrm{h}^{-1}$, respectively. However, there is no statistical significant difference between the arsenic amounts of plants challenged with inorganic arsenic $(P>0.05)$. In comparison to plants challenged with DMA, there is a difference to all $\mathrm{As}^{\mathrm{V}}$ contaminated plants $(P<0.05)$.

Younger plants before the flowering stage in this study were able to restrict arsenic loading into the xylem at high $\mathrm{As}^{\mathrm{V}}$ concentrations in the nutrient solution. This and the reduced sap flow are leading to a significantly reduced arsenic amount compared to low $\mathrm{As}^{\mathrm{V}}$ exposure.

In contrast, older plants are not able to restrict $\mathrm{As}^{\mathrm{V}}$ loading into the xylem effectively when treated with increasing $\mathrm{As}^{\mathrm{V}}$ concentration. Even the reduced sap flow cannot compensate for the increased arsenic concentration in the sap, leading to statistically similar arsenic amounts at different concentrations. High $\mathrm{As}^{\mathrm{V}}$ concentrations in the nutrient solution and low phosphate status will lead to highly efficient uptake of As into the root cells. This resulting high influx may saturate the arsenate reductase, an 
Table 2 | Arsenic concentration and speciation of sap samples of plant set B and plant set $C$ after challenge with $1000 \mu \mathrm{g} \mathrm{kg}^{-1} \mathrm{DMA}, 100,500$, and $1000 \mu \mathrm{g} \mathrm{kg}^{-1} \mathrm{As}^{\mathrm{V}}$ for $24 \mathrm{~h}$.

\begin{tabular}{|c|c|c|c|c|c|}
\hline $\begin{array}{l}\text { Arsenic } \\
\text { species }\end{array}$ & $c(A s)$ in nutrient sol ${ }^{1}(\mu \mathrm{g} / \mathrm{kg})$ & $c(D M A)^{2}$ in sap $(\mu \mathrm{g} / \mathrm{kg})$ & $\mathrm{c}(\mathrm{MMA})^{2}$ in sap $(\mu \mathrm{g} / \mathrm{kg})$ & c(As' $\left.{ }^{\prime \prime \prime}\right)$ in sap $(\mu \mathrm{g} / \mathrm{kg})$ & $c(A s V)$ in sap $(\mu \mathrm{g} / \mathrm{kg})$ \\
\hline B DMA & 1117 & $97.3 \pm 15.5$ & n.d. & n.d. & n.d. \\
\hline \multirow{2}{*}{$B A s^{V}$} & 567 & n.d. & n.d. & $1.5 \pm 0.4$ & n.d. \\
\hline & 909 & Traces & n.d. & $9.9 \pm 4.6$ & n.d. \\
\hline C DMA & 759 & $60.3 \pm 3.6$ & n.d. & n.d. & n.d. \\
\hline \multirow{2}{*}{$\mathrm{CAs}^{\mathrm{V}}$} & 554 & n.d. & n.d. & $13.2 \pm 0.6$ & $23.4 \pm 8.6$ \\
\hline & 759 & Traces & n.d. & $23.2 \pm 4.8$ & $47.7 \pm 1.1$ \\
\hline
\end{tabular}

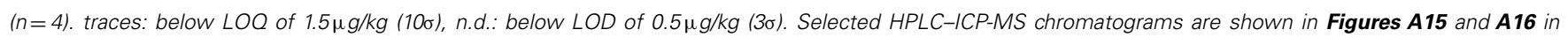
appendices in the supplement.

${ }^{1}$ Before treatment; ${ }^{2}$ expressed as $\mu \mathrm{g}$ As/ $\mathrm{kg}$.

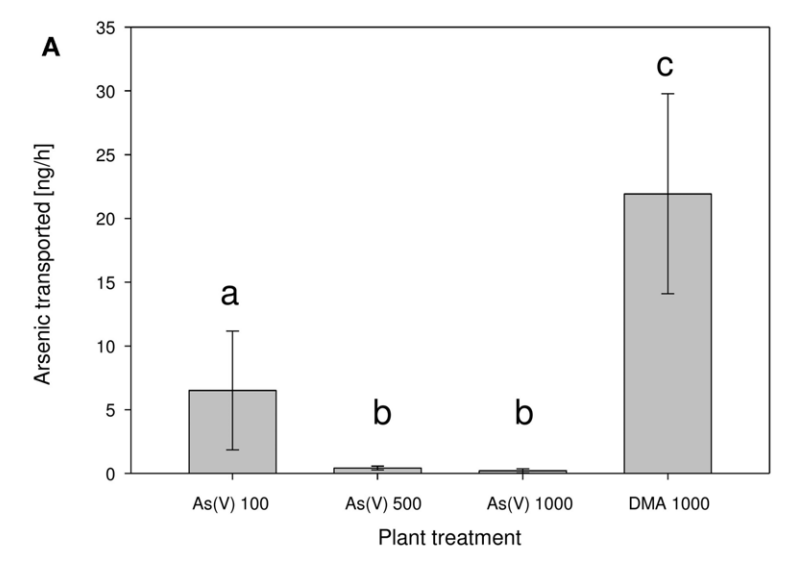

B

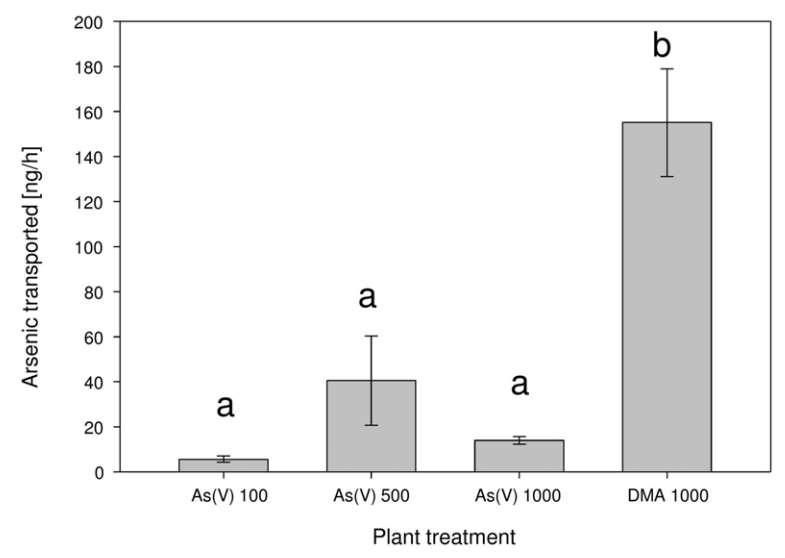

FIGURE 5 | Arsenic amount of sap samples of decapitated cucumbers in experiment $B$ (Figure $5 A$ ) and $C$ (Figure $5 B$ ) after challenge of plants with no arsenic, DMA at $1000 \mu \mathrm{g} \mathrm{kg}^{-1}$ and $A s^{\mathrm{v}}$ at 100, 500, and $\mathbf{1 0 0 0} \mu \mathbf{g ~ k g}^{-1}$ for $\mathbf{2 4} \mathbf{h}$. Sap was collected for $1 \mathrm{~h}(n=4)$. Statistical similarity in one graph is indicated by letter above bar.

enzyme which reduces $\mathrm{As}^{\mathrm{V}}$ to $\mathrm{As}{ }^{\mathrm{III}}$. The effect might be small but a species-specific transport into the xylem may change the ratio between these redox species. While As ${ }^{\mathrm{III}}$ is efficiently complexed (Raab et al., 2005; Bluemlein et al., 2008) with phytochelatins, this is resulting in higher $\mathrm{As}^{\mathrm{V}}$ loading into the xylem.

Plants treated with high concentrations of DMA do neither show a decreased arsenic amount nor a decreased sap flow. This lack of response indicates the non-existence of toxicity or the absence of a specific defense response by the plant.

\section{DISCUSSION}

This metabolite study is the first available which is focused on the impact of arsenic stress on the organic composition of xylem sap. So far, only iron-deficient plants were used for targeted metabolite analysis. The concentration of organic anions in xylem sap was monitored in iron-deficient Lycopersicon esculentum L. (tomato), which resulted in a significant change of the organic anion composition (López-Millán et al., 2009). This effect was also monitored in xylem sap of iron-deficient Beta vulgaris (sugar beet; Larbi et al., 2010).

In this study, five $m / z$ values were identified as being up- or down-regulated under arsenate stress, corresponding to five peaks in the LC-MS chromatograms and therefore to five compounds. Four of the compounds were up-regulated, one down-regulated. This up- or down-regulation was not due to the reduced sap flow induced by arsenate stress as shown by the integration of a random $m / z$ value $(m / z 233)$ which was unaffected by As ${ }^{\mathrm{V}}$ treatment. Three of these $m / z$ values can be used as potential biomarkers for either total arsenic concentration or sap flow.

Identification of the down-regulated compound was achieved for isoleucine $(\mathrm{m} / z \mathrm{132})$. The data from the metabolite profiling study and the identification part show that under arsenic stress isoleucine is down-regulated in the xylem sap of cucumbers.

So far, isoleucine has not been found to be involved in the plant response toward arsenic. In Arabidopsis thaliana, isoleucine is part of the $\gamma$-glutamyl-cycle along with all other $20 \alpha$-amino acids. This cycle is thought to be used by plants to transport amino acid inter- and intra cellular since the $\gamma$-glutamyl-enzyme is part of the cell membrane. Interestingly, this cycle is based on the transformation of glutathione, which is also the initial biothiol in the phytochelatin synthesis (leading to As ${ }^{\mathrm{III}}$-PC complexes). 
Furthermore, the genes encoding the enzymes that convert the amino acid (e.g., isoleucine) and glutathione into a 5-L-glutamyl$\mathrm{L}$-amino acid and L-cysteineglycine are closely related to the PC encoding genes (Ohkama-Ohtsu et al., 2009; Destro et al., 2011). It might be that isoleucine is involved in the glutathione production and is therefore consumed under arsenic stress.

Furthermore, isoleucine is a substrate for a plant stress hormone. In Arabidopsis thaliana, (-)-jasmonoyl-L-isoleucine is synthesized from jasmonic acid and L-isoleucine when the plant is attacked by an herbivore, wounded by mechanical means or infected by a pathogen (Svoboda and Boland, 2010; Sato et al., 2011). It might be that $\mathrm{As}^{\mathrm{V}}$ contamination is also causing stress in the roots of cucumbers leading to an increased formation of (-)-jasmonoyl-L-isoleucine and a depletion of $\mathrm{L}$-isoleucine in the roots and subsequently in the sap.

Furthermore, isoleucine along with valine and leucine was decreased in rat plasma and red blood cells when rats were fed with $\mathrm{As}^{\mathrm{V}}$ (Kilroe-Smith and McLoughlin, 1979). Isoleucine-containing enzymes were also identified as playing a role in the arsenic methylation in humans, which are up-regulated under arsenic stress (Wood et al., 2006). However, no function for isoleucine in xylem sap under arsenate stress has so far been described in the literature.

Arsenic concentration and speciation in xylem sap was found to be consistent with other studies. Plants challenged with DMA did transport only DMA in the xylem. Plants challenged with $\mathrm{As}^{\mathrm{V}}$ transported both inorganic arsenic species in the xylem, which is consistent with previous studies (Pickering et al., 2000; Mihucz et al., 2005; Xu et al., 2007). There are probably several factors governing the loading of $A s^{\mathrm{V}}$ into the xylem, including the $A s^{\mathrm{V}}$ reduction capacity of the roots. In this study, xylem sap of plants in the flowering state contains both inorganic arsenic species. The in vivo reduction of $\mathrm{As}^{\mathrm{V}}$ is thought to be done by the enzyme $\mathrm{ACR} 2$, which has shown in vitro $\mathrm{As}^{\mathrm{V}}$ reducing capacity (Bleeker et al., 2006; Ellis et al., 2006). Here, plants which have reached flowering stage had a significantly higher concentration of $A s^{\mathrm{V}}$ in the xylem than younger plants. This leads to the assumption that

- arsenate reductase was not able to quantitatively reduce $\mathrm{As}^{\mathrm{V}}$ to $A s^{I I I}$ in plants at the flowering stage with high xylem sap flow

- the overall arsenic uptake is significantly higher in older plants.

During sap extraction a new arsenic stress effect was observed. With increasing inorganic arsenic stress (i.e., increasing inorganic arsenic concentration in the nutrient solution) a decreased sap flow was monitored. This was first mentioned in a recent publication where castor beans challenged with 3.75 and $7.5 \mathrm{mg} \mathrm{kg}^{-1} \mathrm{As}^{\mathrm{V}}$ did not exudate xylem sap (Ye et al., 2010). In another recent hydroponic study this effect was studied more closely, revealing that xylem sap exudation of cucumbers was significantly reduced at high arsenic levels $\left(7.5 \mathrm{mg} \mathrm{kg}^{-1}\right)$ in the nutrient solution (Czech et al., 2011). Furthermore, leaf transpiration and biomass production were significantly inhibited.

Here, this effect was analyzed in more detail. Decreased sap flow with increased inorganic arsenic stress is consistent for all plant experiments shown in this study. Reduced sap production was not monitored with high concentrations of dimethylated arsenic species. The correlation between sap flow vs. As ${ }^{\mathrm{V}}$ concentration in nutrient solution is linear for younger plants, which have not yet reached flowering stage and older plants which have reached flowering stage. This might be another reason for $\mathrm{As}^{\mathrm{V}}$ toxicity because reduced sap flow could lead to less nutrients and water intake and therefore to lower biomass production. However, it is yet unclear what mechanisms are involved in lower sap production.

The decreased sap flow leads furthermore to a decreased arsenic amount within the plant. Even with increased total arsenic concentration in the xylem, the decreased sap flow is the significant factor. It is interesting that the highest sap amount monitored in plant set A was at the lowest concentration in the nutrient solution. There might be a threshold concentration which triggers the reduction of sap flow.

The decrease in arsenic amount under $\mathrm{As}^{\mathrm{V}}$ stress compared to methylated arsenic could be due to two reasons:

- the plants have a mechanism to shut down sap production in order to avoid arsenic contamination in the xylem and throughout the plant, or

- the concentration of $\mathrm{As}^{\mathrm{V}}$ is already causing toxicity symptoms leading to a decrease in cell functionality.

Usually, the total arsenic concentration in leafs and fruits are higher in plants grown on highly contaminated soil or nutrient solution (Abedin et al., 2002). However, it seems as if translocation factors from roots to shoots are higher when plants are grown on less contaminated soil or nutrient solution as presented later (Caetano et al., 2008). They have investigated the metal retention in belowground and aboveground biomass of salt marsh plants compared to the metal composition in the surrounding marsh. For arsenic they found that plants grown on soil with the highest As concentration had also the highest As concentration in the belowground biomass. Interestingly, those plants had a significantly lower As concentration in the above ground biomass than plants grown on soil with lower As concentration. This means that a large reduction of available arsenic in the soil has only a small effect on the arsenic concentration in the above ground biomass. In another study it was revealed that of 13 different plants grown on 3 different soils with different arsenic concentrations in the surface water, the plants grown on the least contaminated soil had the highest arsenic translocation factor from root to shoot (Zandsalimi et al., 2011). The same effect was observed in a recent study where the highest translocation factors were observed in plants grown on the lowest bio-available arsenic fraction in three different soils (Baig et al., 2011).

These results suggest the hypothesis that there is a concentration threshold at which plants react with their defense mechanisms (phytochelatin synthesis/xylem sap reduction). However, these results raise the question whether concentration data obtained by this xylem sap sampling technique is valid for inter-comparison (control-challenged plants). The significant reduction of sap production could have a significant influence on the arsenic loading.

\section{ACKNOWLEDGMENTS}

We thank Dr. Sabine Freitag for her help with PCA and critically reading this manuscript. This study was funded by EPSRC (EP/E061303). 


\section{REFERENCES}

Abedin, M. J., Cotter-Howells, J., and Meharg, A. A. (2002). Arsenic uptake and accumulation in rice (Oryza sativa L.) irrigated with contaminated water. Plant Soil 240, 311-319.

Baig, J. A., Kazi, T. G., Shah, A. Q., Afridi, H. I., Kandhro, G. A., Khan, S., Kolachi, N. F., Wadhwa, S. K., Shah, F., Arain, M. B., and Jamali, M. K. (2011). Evaluation of arsenic levels in grain crops samples, irrigated by tube well and canal water. Food Chem. Toxicol. 49, 265-270.

Bleeker, P. M., Hakvoort, H. W. J., Bliek, M., Souer, E., and Schat, H. (2006). Enhanced arsenate reduction by a CDC25-like tyrosine phosphatase explains increased phytochelatin accumulation in arsenate-tolerant Holcus lanatus. Plant J. 45, 917-929.

Bluemlein, K., Raab, A., Meharg, A. A., Charnock, J. M., and Feldmann, J. (2008). Can we trust mass spectrometry for determination of arsenic peptides in plants: comparison of LC-ICP-MS and LC-ES-MS/ICPMS with XANES/EXAFS in analysis of Thunbergia alata. Anal. Bioanal. Chem. 390, 1739-1751.

Caetano, M., Vale, C., Cesário, R., and Fonseca, N. (2008). Evidence for preferential depths of metal retention in roots of salt marsh plants. Sci. Total Environ. 390, 466-474.

Callahan, D. L., De Souza, D., Bacic, A., and Roessner, U. (2009). Profiling of polar metabolites in biological extracts using diamond hydridebased aqueous normal phase chromatography. J. Sep. Sci. 32, 2273-2280.

Carey, A. M., Scheckel, K. G., Lombi, E., Newville, M., Choi, Y., Norton, G. J., Charnock, J. M., Feldmann, J., Price, A. H., and Meharg, A. A. (2010). Grain unloading of arsenic species in rice. Plant Physiol. 152, 309-319.

Czech, V., Cseh, E., and Fodor, F. (2011). Arsenate induces water stress. J. Plant Nutr. 34, 60-70.

Destro, T., Prasad, D., Martignago, D., Lliso Bernet, I., Trentin, A. R., Renu, I. K., Ferretti, M., and Masi, A. (2011). Compensatory expression and substrate inducibility of $\gamma$ glutamyl transferase GGT2 isoform in Arabidopsis thaliana. J. Exp. Bot. 62, 805-814.

Ducruix, C., Vailhen, D., Werner, E., Fievet, J. B., Bourguignon, J., Tabet, J. C., Ezan, E., and Junot, C. (2008). Metabolomic investigation of the response of the model plant Arabidopsis thaliana to cadmium exposure: evaluation of data pretreatment methods for further statistical analyses. Chemom. Intell. Lab. Syst. 91, 67-77.
Ellis, D. R., Gumaelius, L., Indriolo, E., Pickering, I. J., Banks, J. A., and Salt, D. E. (2006). A novel arsenate reductase from the arsenic hyperaccumulating fern Pteris vittata. Plant Physiol. 141, 1544-1554.

Heikens, A., Panaullah, G. M., and Meharg, A. A. (2007). Arsenic behaviour from groundwater and soil to crops: impacts on agriculture and food safety. Rev. Environ. Contam. Toxicol. 189, 43-87.

Hossain, M. F. (2006). Arsenic contamination in Bangladesh - an overview. Agric. Ecosyst. Environ. 113, 1-16.

Jahangir, M., Abdel-Farid, I. B., Choi, Y. H., and Verpoorte, R. (2008). Metal ion-inducing metabolite accumulation in Brassica rapa. J. Plant Physiol. 165, 1429-1437.

Jarvis, R. M., Broadhurst, D., Johnson, H., O'Boyle, N. M., and Goodacre R. (2006). PYCHEM: a multivariate analysis package for python. Bioinformatics 22, 2565-2566.

Jian, F. M., Yamaji, N., Mitani, N., Xu, X. Y., Su, Y. H., Mcgrath, S. P., and Zhao, F. J. (2008). Transporters of arsenite in rice and their role in arsenic accumulation in rice grain. Proc. Natl. Acad. Sci. U.S.A. 105, 9931-9935.

Karim, M. M. (2000). Arsenic in groundwater and health problems in Bangladesh. Water Res. 34, 304-310.

Kertulis, G. M., Ma, L. Q., Macdonald, G. E., Chen, R., Winefordner, J. D., and Cai, Y. (2005). Arsenic speciation and transport in Pteris vittata L. and the effects on phosphorus in the xylem sap. Environ. Exp. Bot. 54, 239-247.

Kilroe-Smith, T. A., and McLoughlin, J. L. (1979). The effects of sodium arsenate on the free amino acid levels in erythrocytes and plasma in rats. Chem. Biol. Interact. 28, 161-170.

Larbi, A., Morales, F., Abadía, A., and Abadía, J. (2010). Changes in iron and organic acid concentrations in xylem sap and apoplastic fluid of iron-deficient Beta vulgaris plants in response to iron resupply. J. Plant Physiol. 167, 255-260.

Liu, W. J., Wood, B. A., Raab, A., Mcgrath, S. P., Zhao, F. J., and Feldmann, J. (2010). Complexation of arsenite with phytochelatins reduces arsenite efflux and translocation from roots to shoots in Arabidopsis. Plant Physiol. 152, 2211-2221.

López-Millán, A. F., Morales, F., Gogorcena, Y., Abadía, A., and Abadía, J. (2009). Metabolic responses in iron deficient tomato plants. J. Plant Physiol. 166, 375-384.

Ma, J. F., Yamaji, N., Mitani, N., Tamai, K., Konishi, S., Fujiwara, T., Katsuhara, M., and Yano, M. (2007). An efflux transporter of silicon in rice. Nature 448, 209-212.
Meharg, A. A., and Jardine, L. (2003). Arsenite transport into paddy rice (Oryza sativa) roots. New Phytol. 157, 39-44.

Meharg, A. A., and Macnair, M. R. (1992). Suppression of the high affinity phosphate uptake system: a mechanism of arsenate tolerance in Holcus lanatus L. J. Exp. Bot. 43, 519-524.

Meirer, F., Pepponi, G., Streli, C., Wobrauschek, P., Mihucz, V. G., Zaíray, G., Czech, V., Broekaert, J. A. C., Fittschen, U. E. A., and Falkenberg, G. (2007). Application of synchrotron-radiation-induced TXRF-XANES for arsenic speciation in cucumber (Cucumis sativus L.) xylem sap. X-Ray Spectrom. 36, 408-412.

Mihucz, V. G., Tatár, E., Virág, I., Cseh, E., Fodor, F., and Záray, G. (2005). Arsenic speciation in xylem sap of cucumber (Cucumis sativus L.). Anal. Bioanal. Chem. 383, 461-466.

Ohkama-Ohtsu, N., Fukuyama, K., and Oliver, D. J. (2009). Roles of $\gamma$-glutamyl transpeptidase and $\gamma$-glutamyl cyclotransferase in glutathione and glutathione-conjugate metabolism in plants. Adv. Bot. Res. 52, 87-113.

Ouyang, Y. (2005). Phytoextraction: simulating uptake and translocation of arsenic in a soil-plant system. Int. J. Phytoremediation 7, 3-17.

Pickering, I. J., Prince, R. C., George, M. J., Smith, R. D., George, G. N., and Salt, D. E. (2000). Reduction and coordination of arsenic in Indian mustard. Plant Physiol. 122, 1171-1177.

Raab, A., Feldmann, J., and Meharg, A. A. (2004). The nature of arsenicphytochelatin complexes in Holcus lanatus and Pteris cretica. Plant Physiol. 134, 1113-1122.

Raab, A., Schat, H., Meharg, A. A. and Feldmann, J. (2005). Uptake, translocation and transformation of arsenate and arsenite in sunflower (Helianthus annuus): formation of arsenic-phytochelatin complexes during exposure to high arsenic concentrations. New Phytol. 168, 551-558.

Sato, C., Aikawa, K., Sugiyama, S., Nabeta, K., Masuta, C., and Matsuura, H. (2011). Distal transport of exogenously applied jasmonoyl-isoleucine with wounding stress. Plant Cell Physiol. 52, 509-517.

Schmoger, M. E. V., Oven, M., and Grill, E. (2000). Detoxification of arsenic by phytochelatins in plants. Plant Physiol. 122, 793-801.

Svoboda, J., and Boland, W. (2010). Plant defense elicitors: analogues of jasmonoyl-isoleucine conjugate. Phytochemistry 71, 1445-1449.

Wang, J., Zhao, F. J., Meharg, A. A., Raab, A., Feldmann, J., and Mcgrath, S. P. (2002). Mechanisms of arsenic hyperaccumulation in Pteris vittata. Uptake kinetics, interactions with phosphate, and arsenic speciation. Plant Physiol. 130, 1552-1561.

Williams, P. N., Price, A. H., Raab, A., Hossain, S. A., Feldmann, J., and Meharg, A. A. (2005). Variation in arsenic speciation and concentration in paddy rice related to dietary exposure. Environ. Sci. Technol. 39, 5531-5540.

Wood, T. C., Salavagionne, O. E., Mukherjee, B., Wang, L., Klumpp, A. F., Thomae, B. A., Eckloff, B. W., Schaid, D. J., Wieben, E. D., and Weinshilboum, R. M. (2006). Human arsenic methyltransferase (AS3MT) pharmacogenetics: gene resequencing and functional genomics studies. J. Biol. Chem. 281, 7364-7373.

Xu, X. Y., Mcgrath, S. P., and Zhao, F. J. (2007). Rapid reduction of arsenate in the medium mediated by plant roots. New Phytol. 176, 590-599.

Ye, W. L., Wood, B. A., Stroud, J. L., Andralojc, P. J., Raab, A., Mcgrath, S. P., Feldmann, J., and Zhao, F. J. (2010). Arsenic speciation in phloem and xylem exudates of castor bean. Plant Physiol. 154, 1505-1513.

Zandsalimi, S., Karimi, N., and Kohandel, A. (2011). Arsenic in soil, vegetation and water of a contaminated region. Int. J. Environ. Sci. Technol. 8, 331-338.

Conflict of Interest Statement: The authors declare that the research was conducted in the absence of any commercial or financial relationships that could be construed as a potential conflict of interest.

Received: 18 January 2012; accepted: 27 February 2012; published online: 02 April 2012.

Citation: Uroic MK, Salaün P, Raab A and Feldmann J (2012) Arsenate impact on the metabolite profile, production, and arsenic loading of xylem sap in cucumbers (Cucumis sativus L.). Front. Physio. 3:55. doi: 10.3389/fphys.2012.00055

This article was submitted to Frontiers in Plant Physiology, a specialty of Frontiers in Physiology.

Copyright (C) 2012 Uroic, Salaün, Raab and Feldmann. This is an open-access article distributed under the terms of the Creative Commons Attribution Non Commercial License, which permits noncommercial use, distribution, and reproduction in other forums, provided the original authors and source are credited. 


\section{APPENDIX}

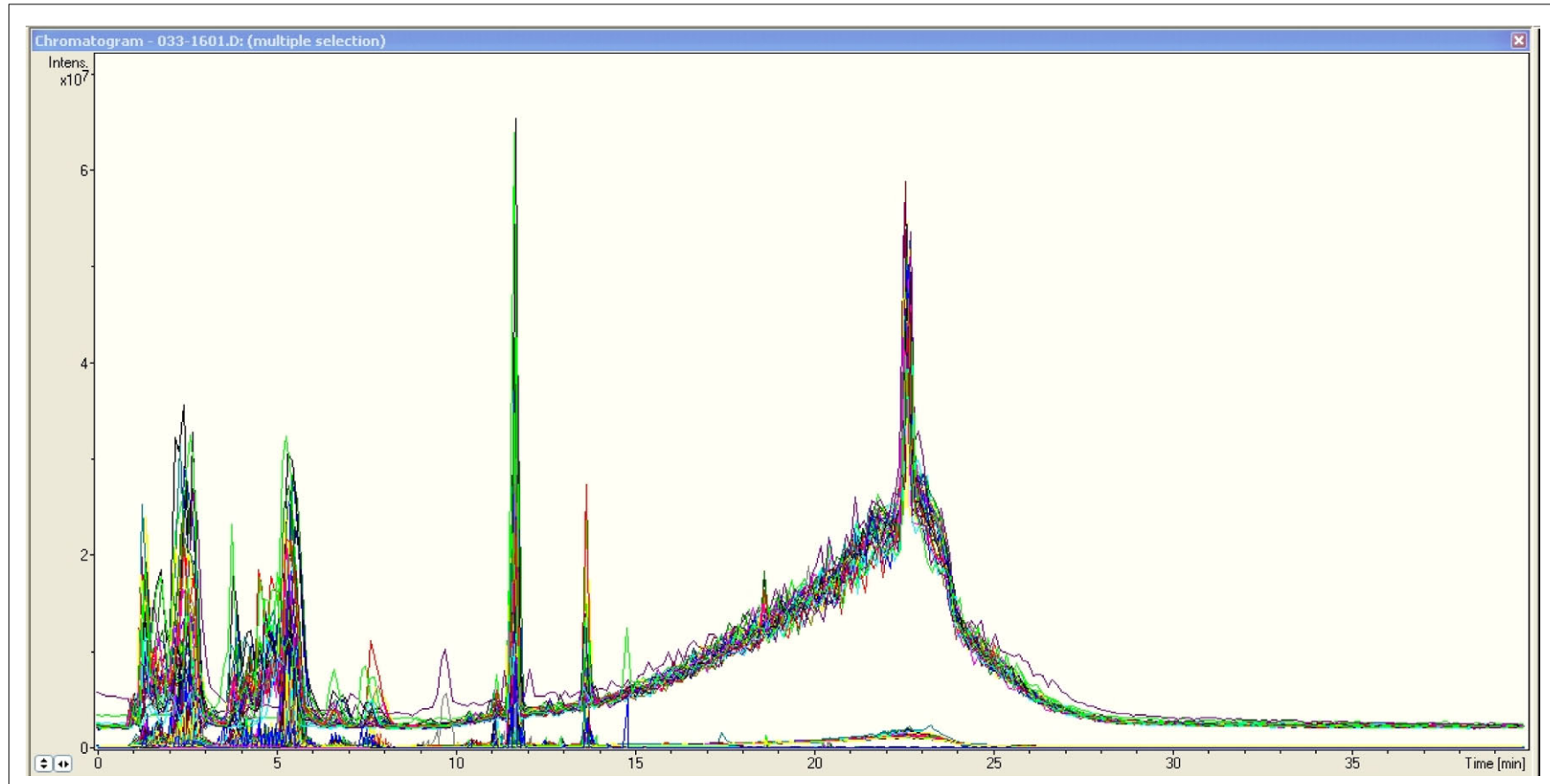

FIGURE A1 | RP-HPLC-ESI-MS total ion chromatograms of all 32 sap samples from plant set A.

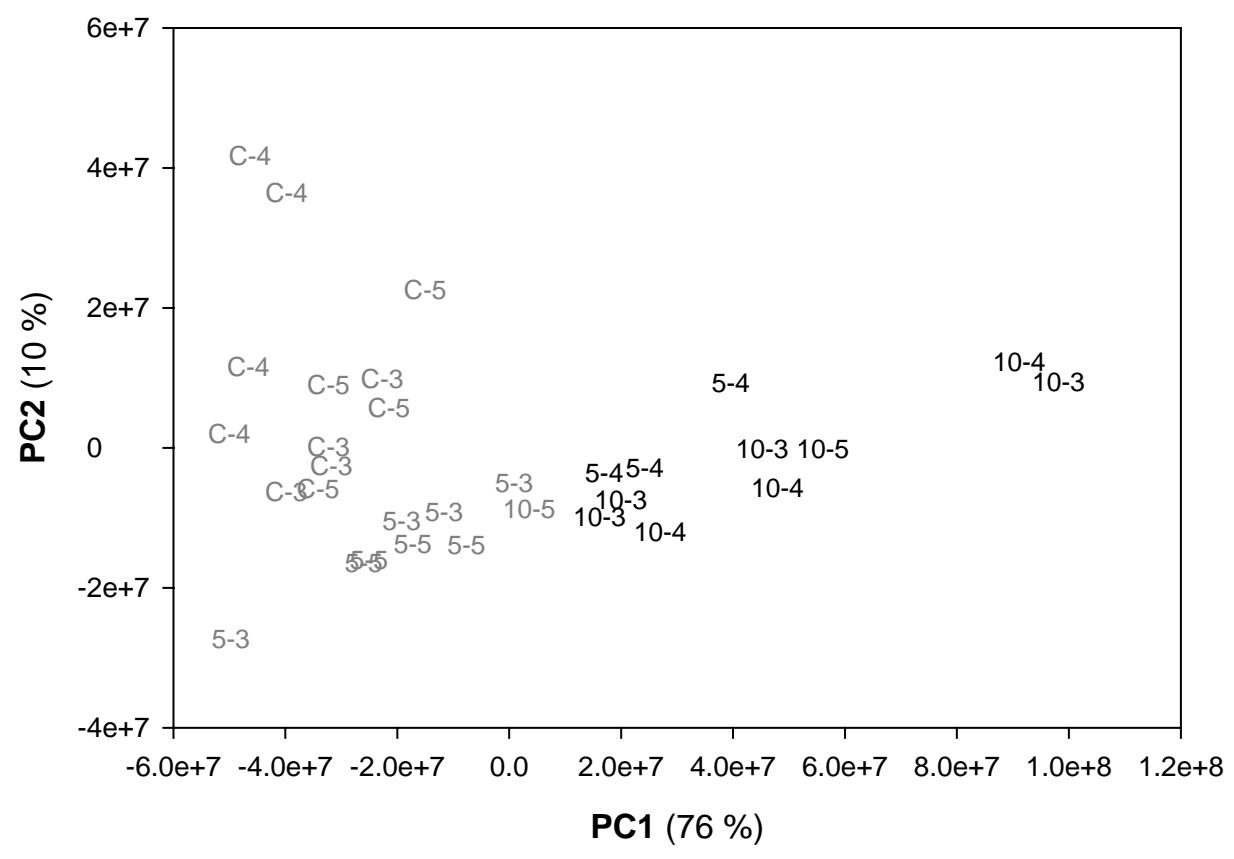

FIGURE A2 | PCA score plot of PC1 vs PC2 of the HPLC-ESI-MS obtained from plant set A. Gray numbers: Group A, black numbers: group B according to cluster analysis. Letters and numbers are coded as: 10-3: $10=$ arsenate concentration in nutrient solution $\left(1000 \mu \mathrm{g} \mathrm{kg}^{-1}\right) ; 3=$ pot number, there were four plants in one pot. 


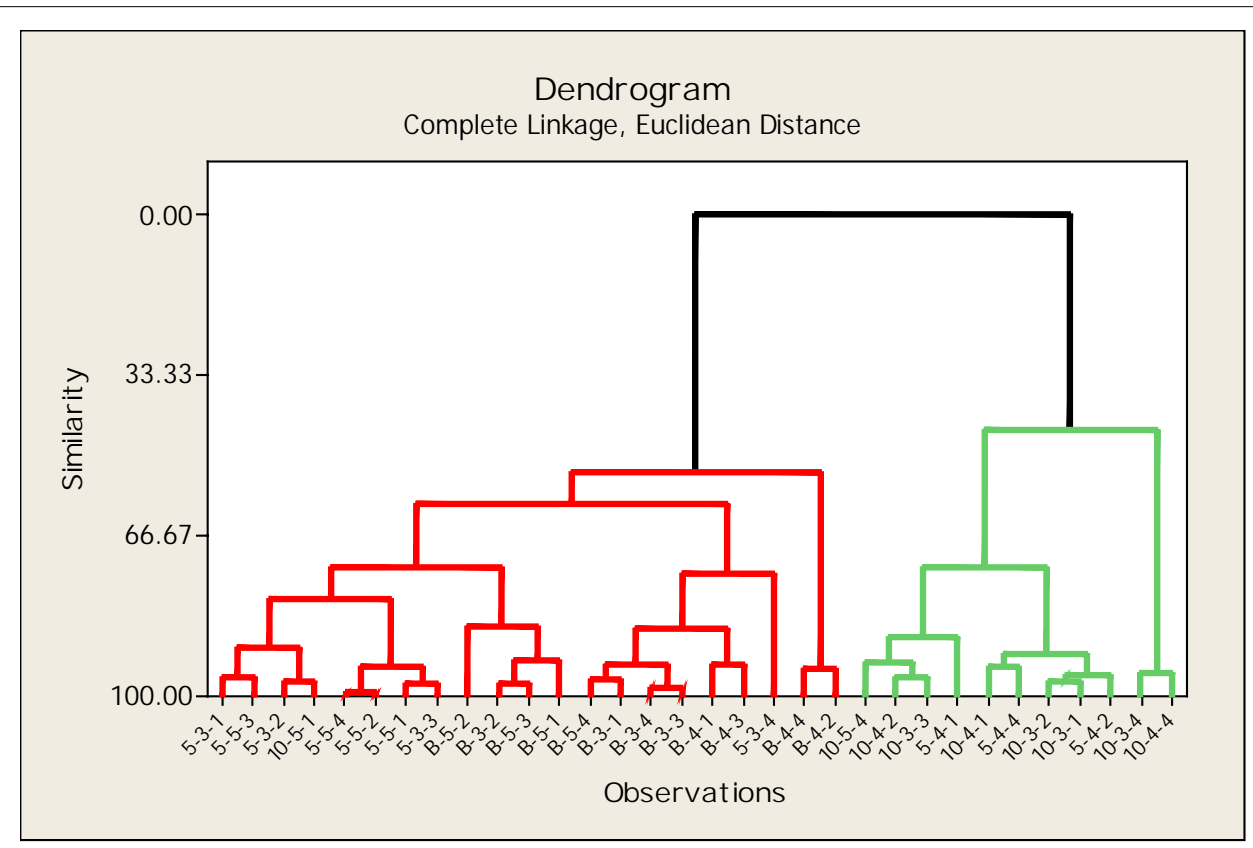

FIGURE A3 | Dendrogram of the data points in PCA score plot of plant set A using two clusters, calculated by using the Euclidean distance with complete linkage.

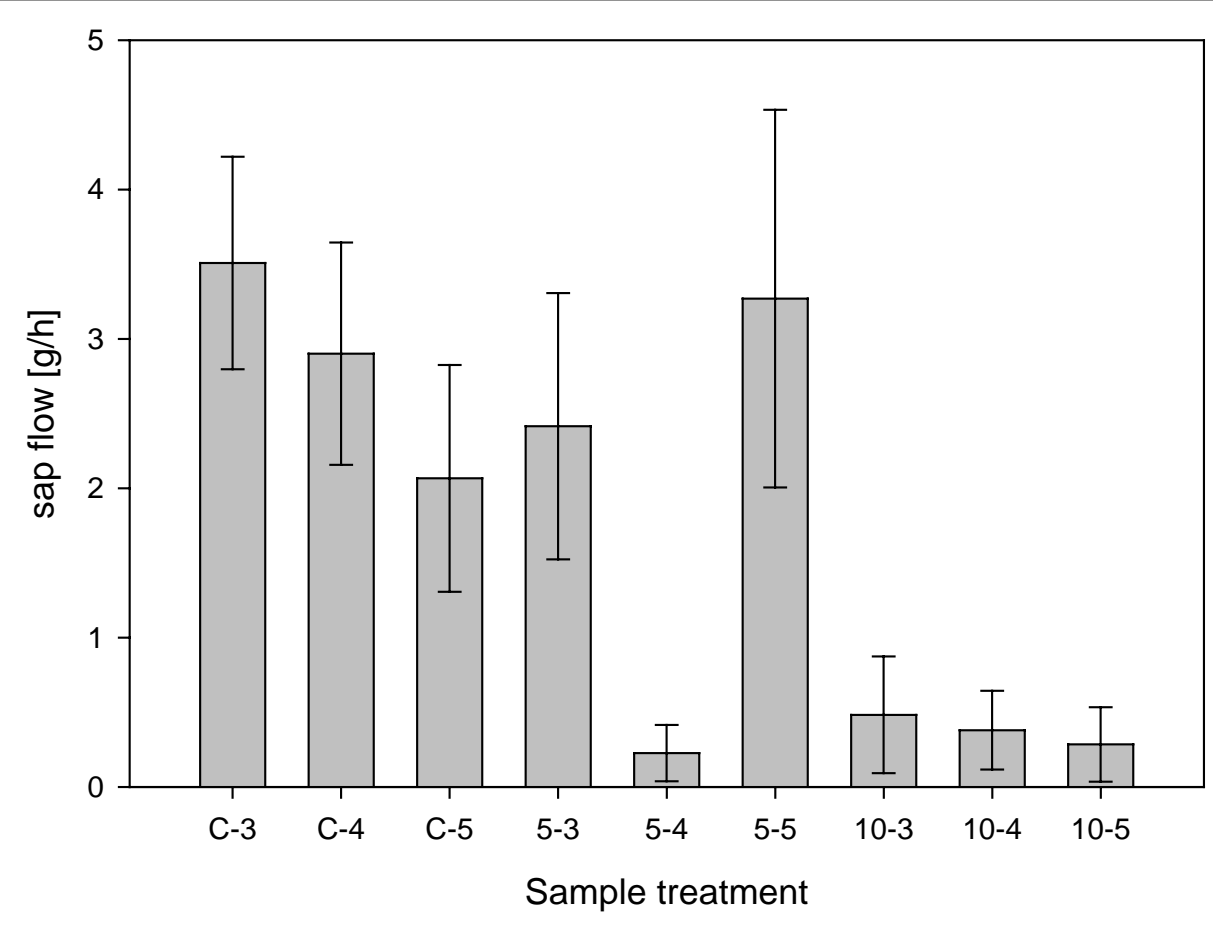

FIGURE A4 | Xylem sap flow of cucumbers subjected to different arsenic treatment: No arsenic (C-x), 5-3: 677 $\mu \mathrm{g} / \mathrm{kg}$; 5-4: $666 \mu \mathrm{g} / \mathrm{kg} ; 5-5: 791 \mu \mathrm{g} / \mathrm{kg}$; 10-3: $1405 \mu \mathrm{g} / \mathrm{kg} ; 10-4: 1407 \mu \mathrm{g} / \mathrm{kg} ; 1405 \mu \mathrm{g} / \mathrm{kg}$, $(n=4)$. 


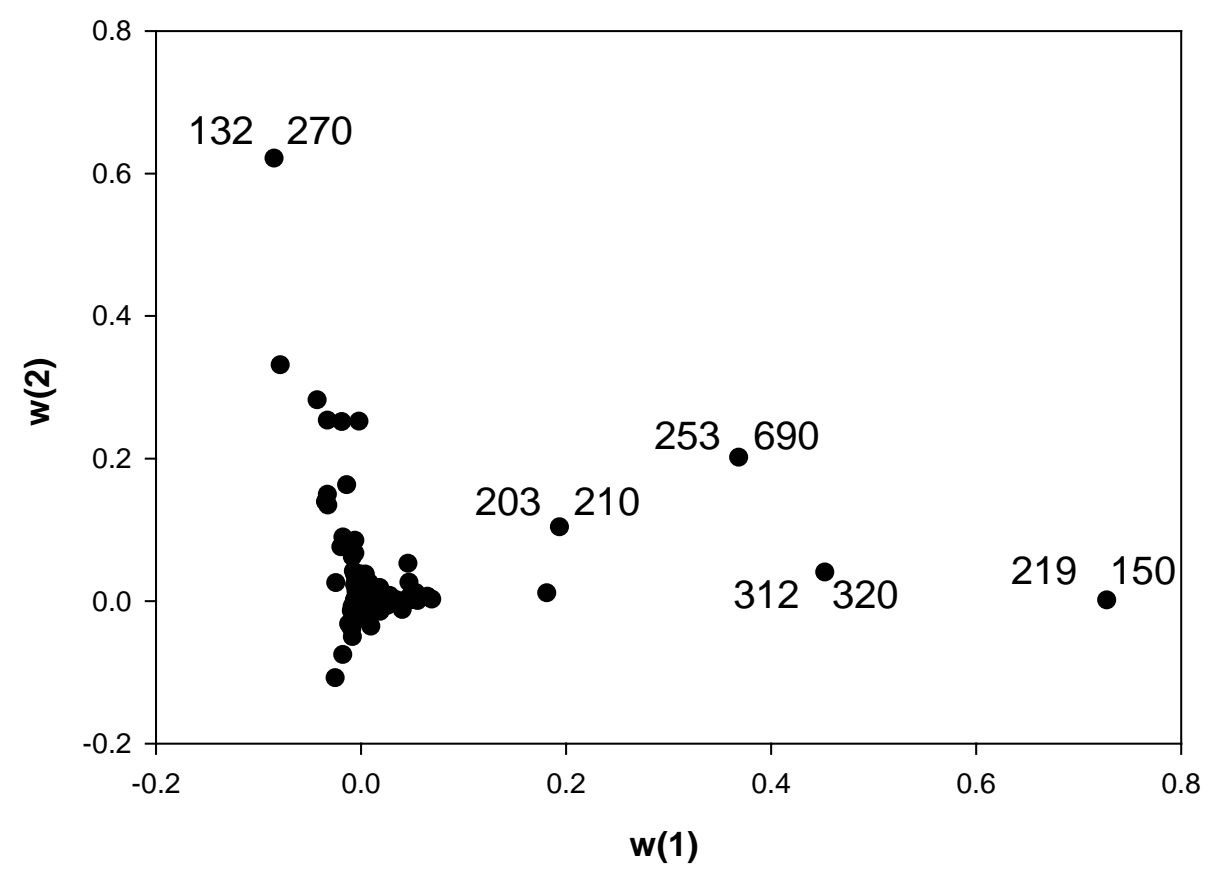

FIGURE A5 | PCA loadings plot of weighting 1 vs weighting 2 of the LC-MS runs of respected $\mathbf{t R}$ and $\mathbf{m} / \mathbf{z}$ obtained from plant set C. PC1: $76 \%$, PC2: $10 \%$. Numbers given are $\mathrm{m} / \mathrm{z}$ (three digits) followed by retention time in seconds (three digits). 


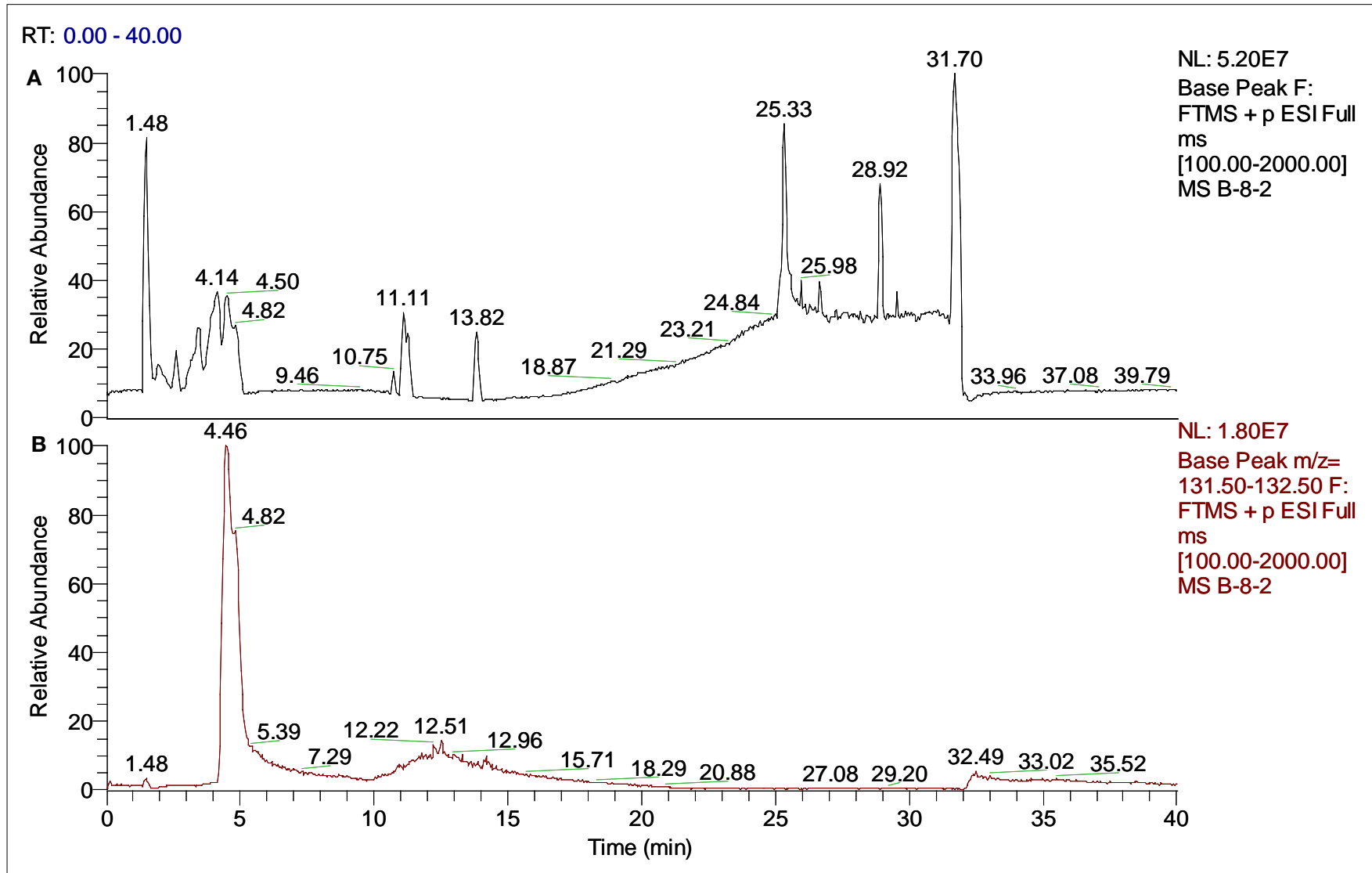

FIGURE A6 | RP-HPLC-ESI-MS (Orbitrap) base peak chromatograms of xylem sap of plants not challenged with arsenate. (A) the whole mass range $(\mathrm{m} / \mathrm{z}$ 100-2000) and (B) the mass range $\mathrm{m} / \mathrm{z}$ 131.50-132.50. 


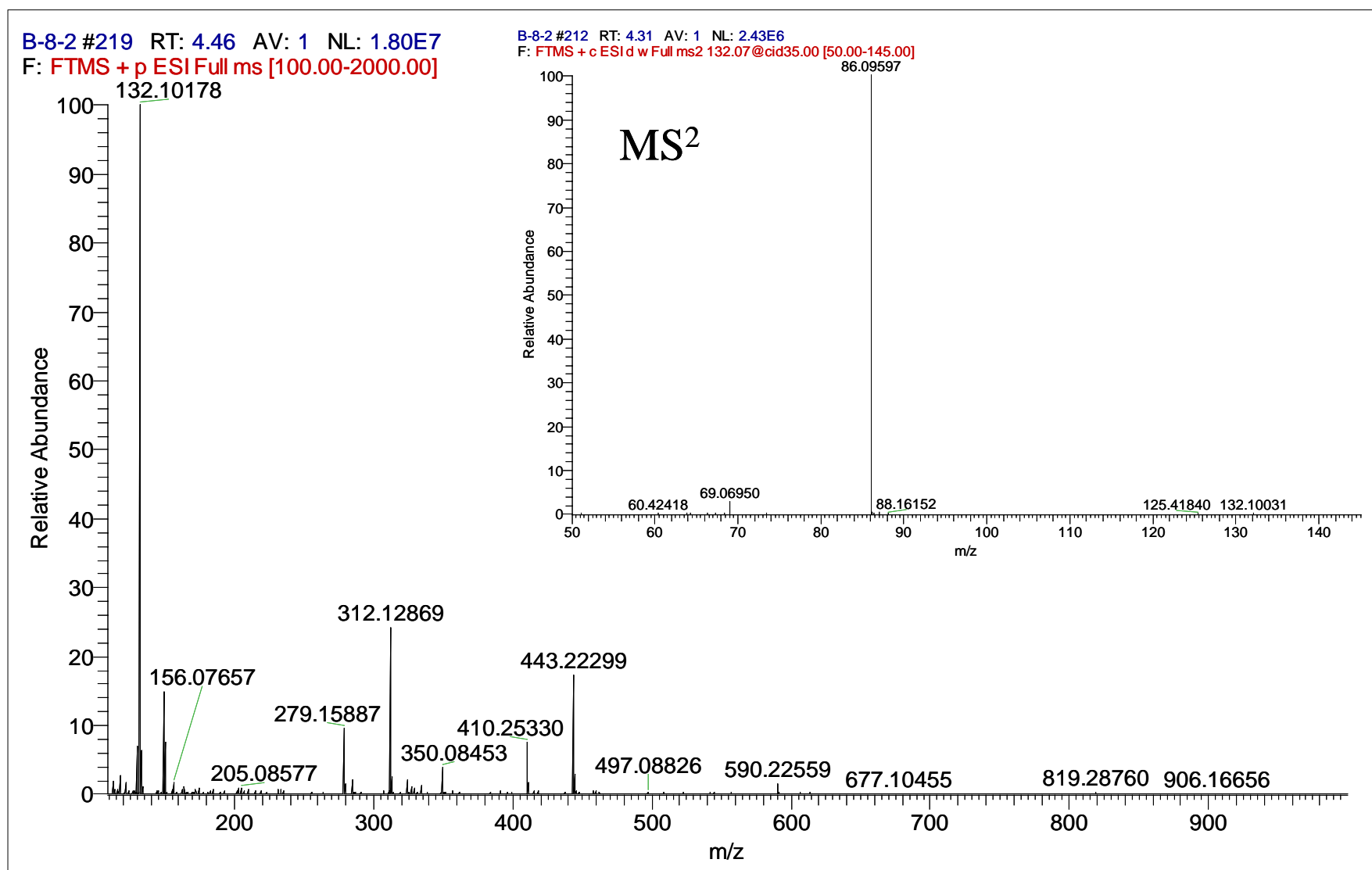

FIGURE A7 | Accurate mass MS and MS2 of $\mathrm{m} / \mathrm{z} 132$ at $4.46 \mathrm{~min}$. 


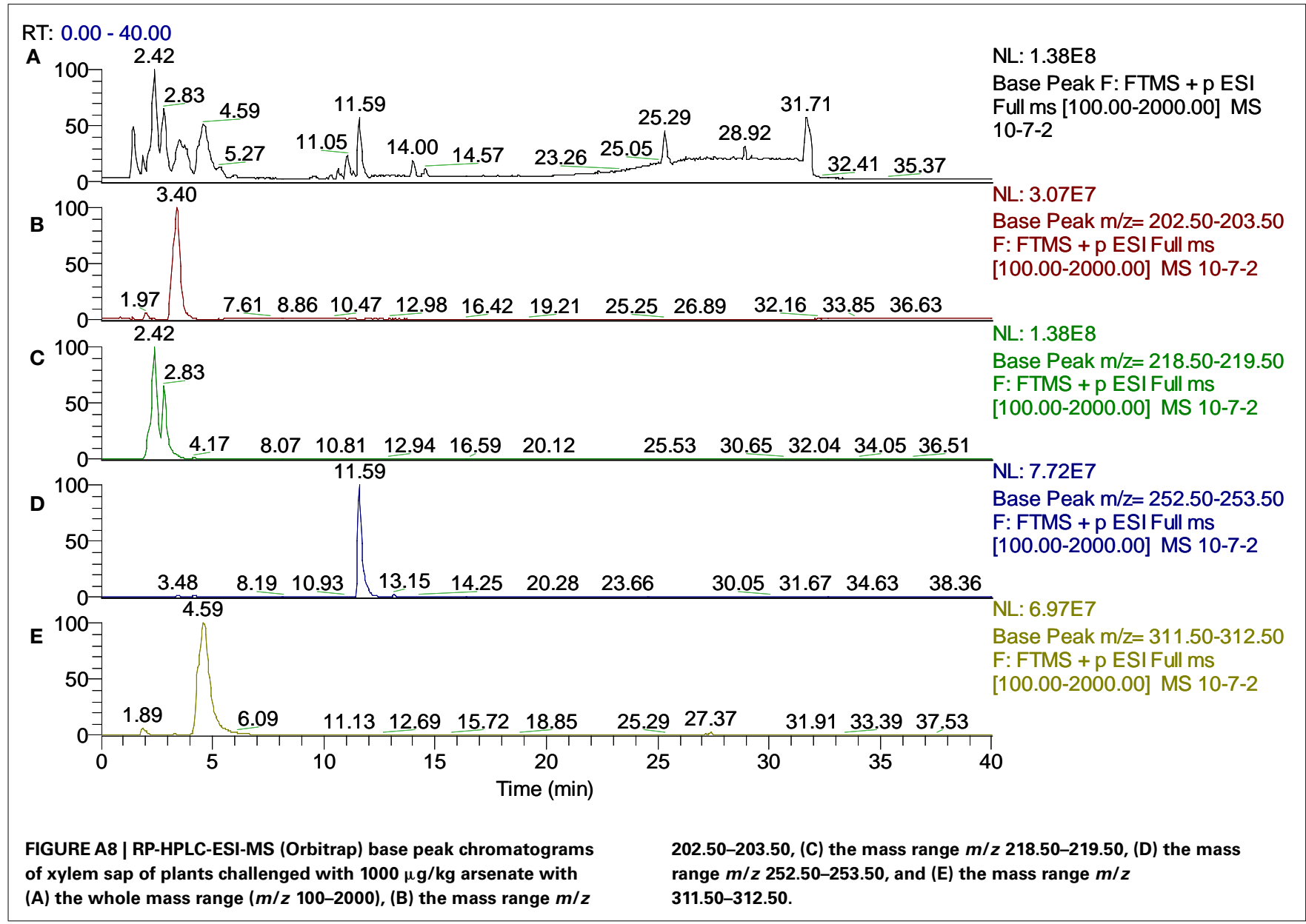




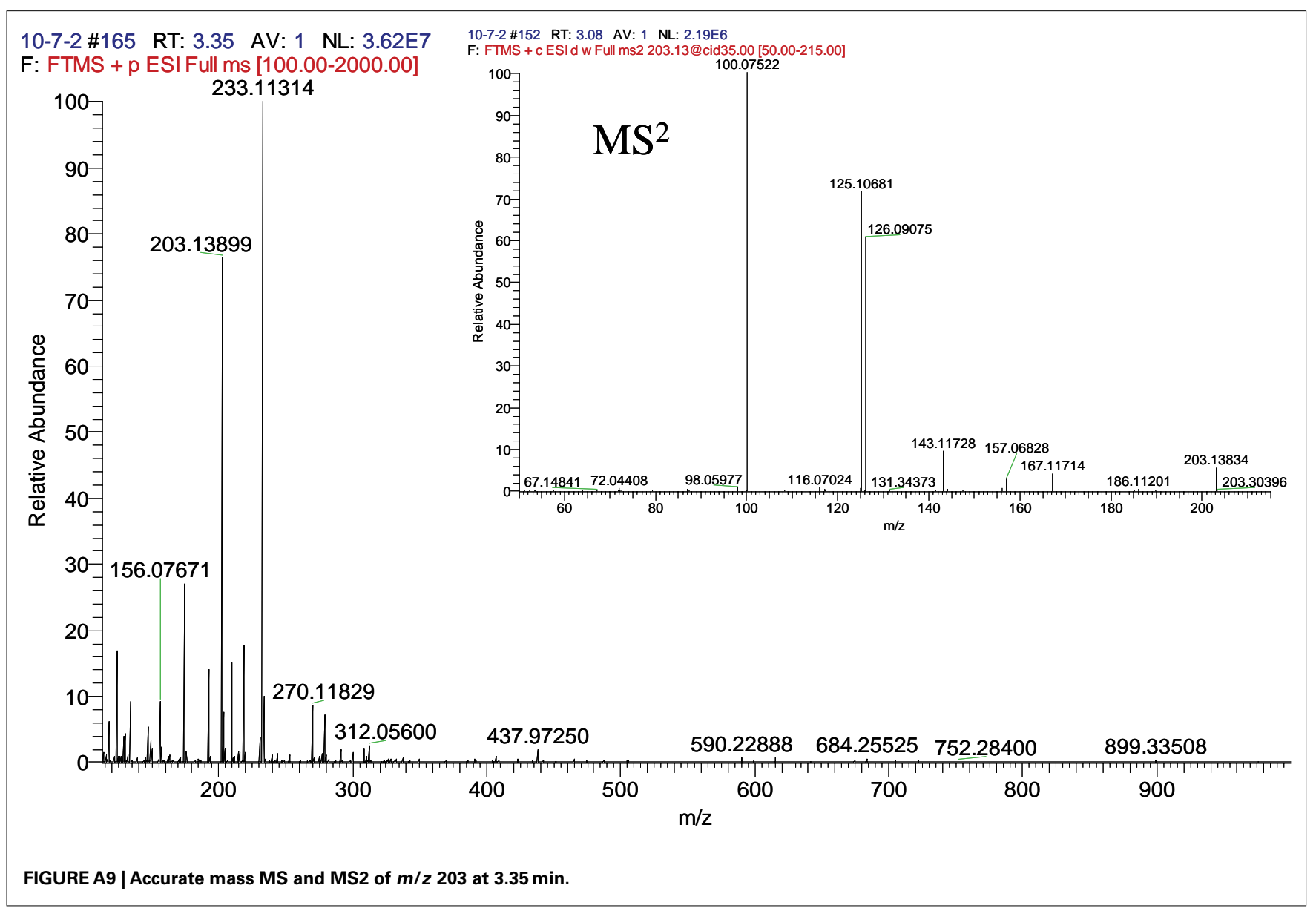




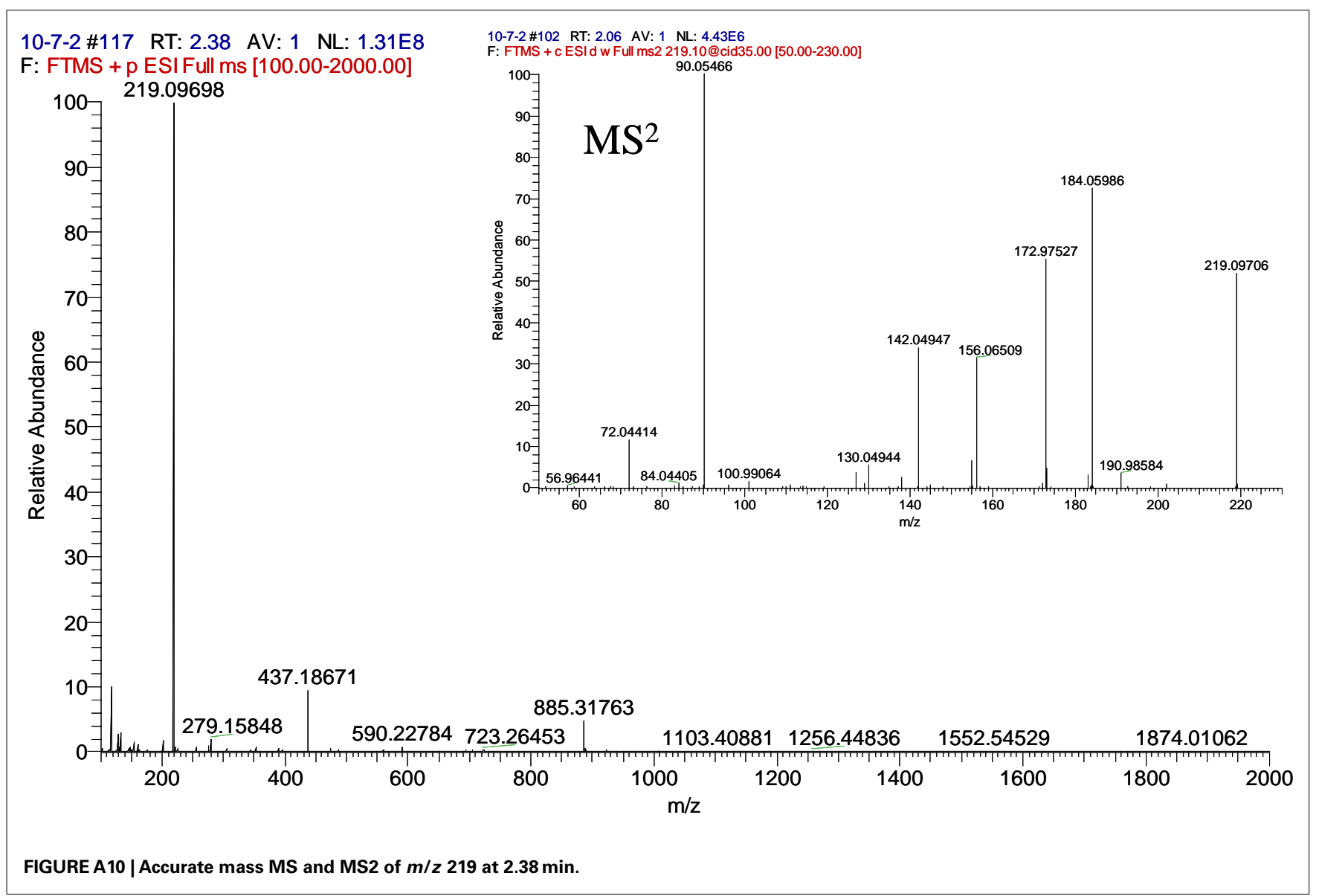




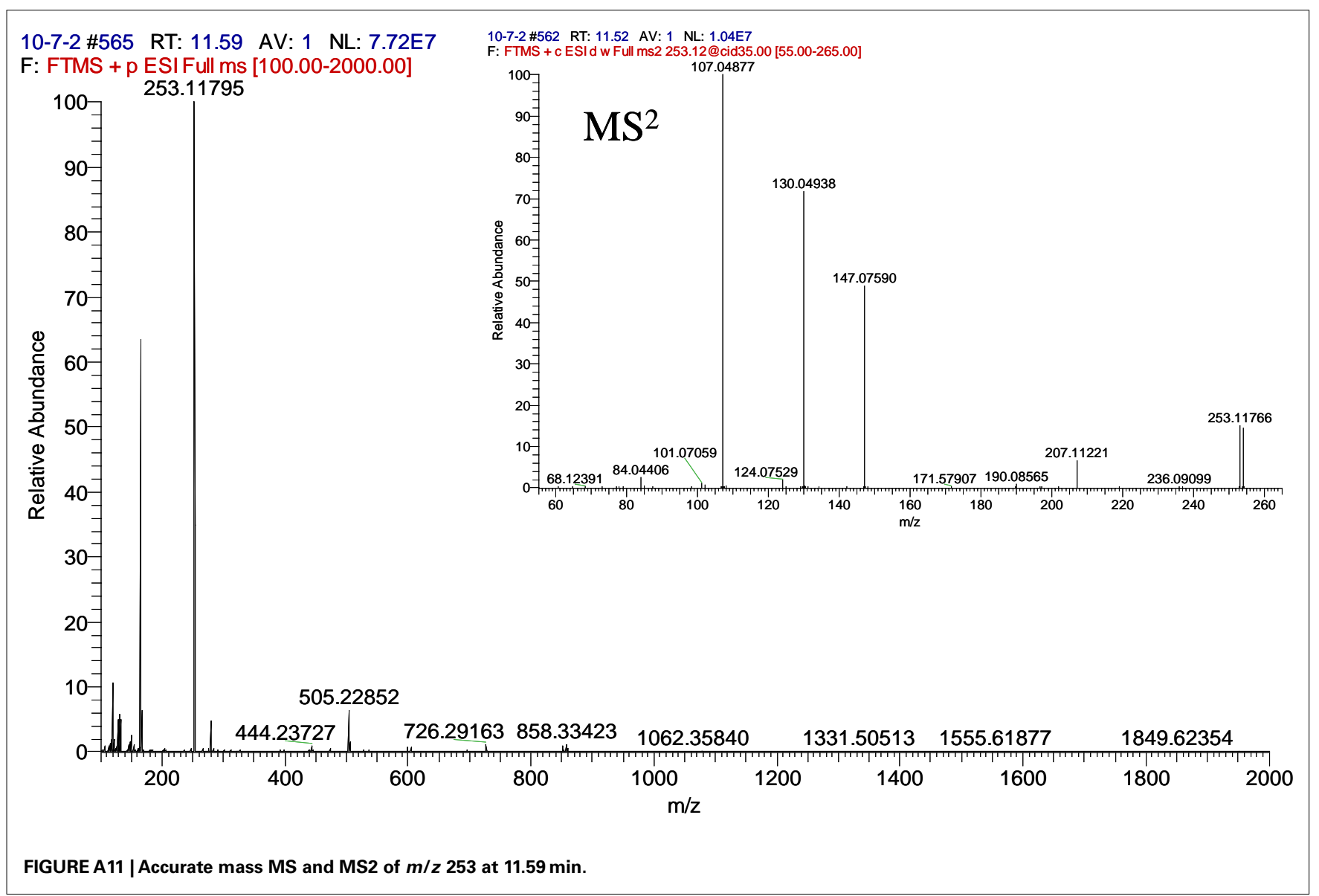




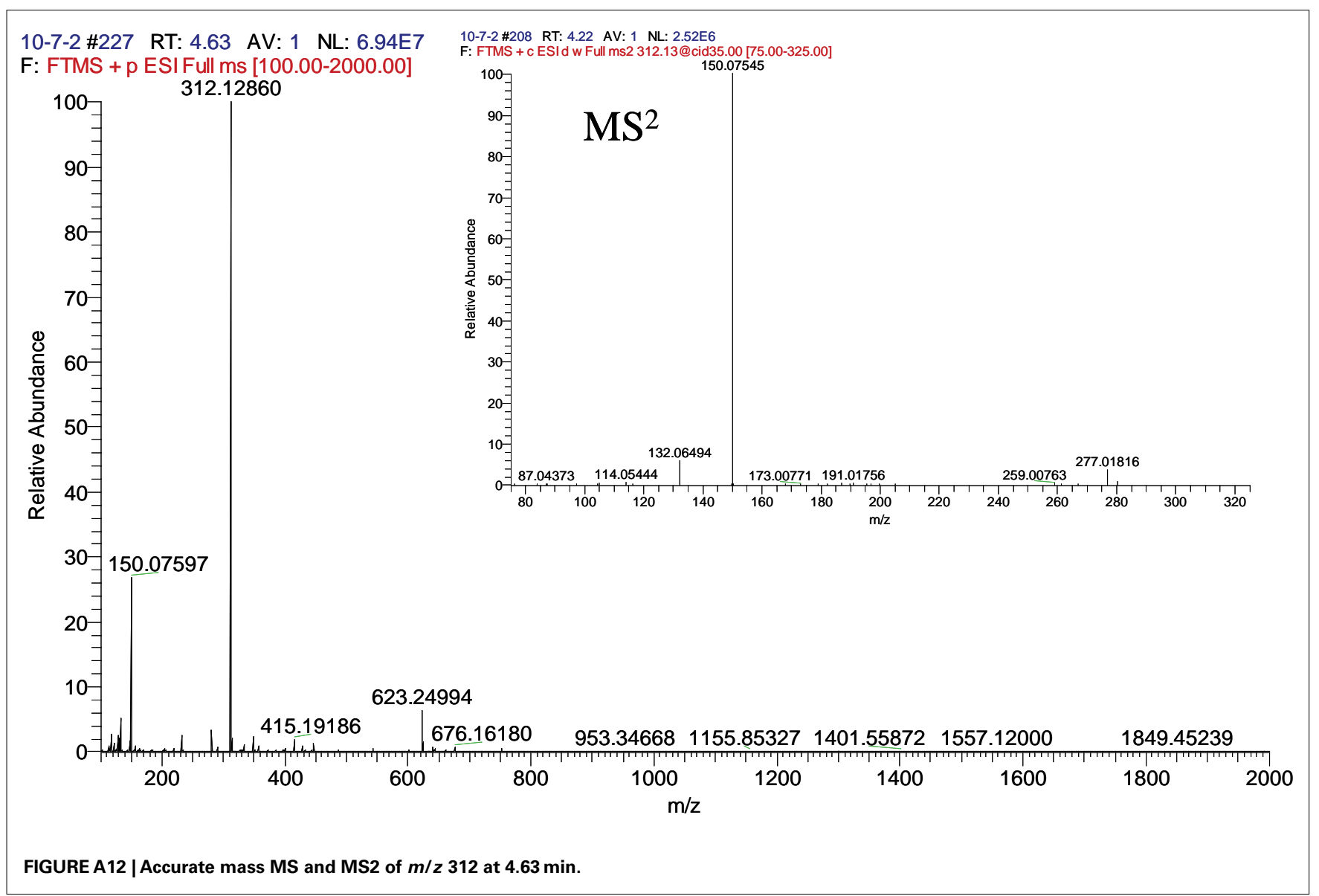




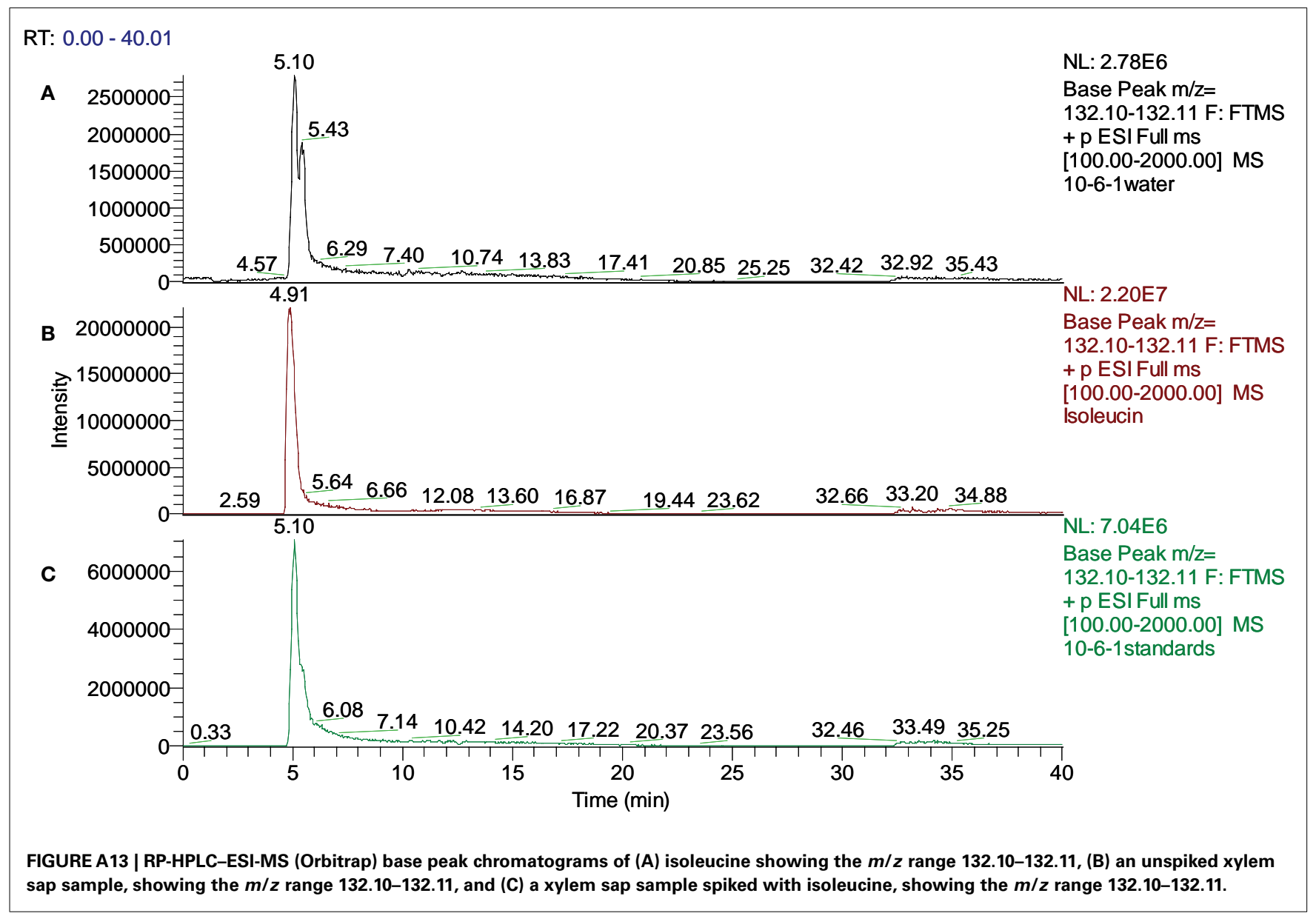




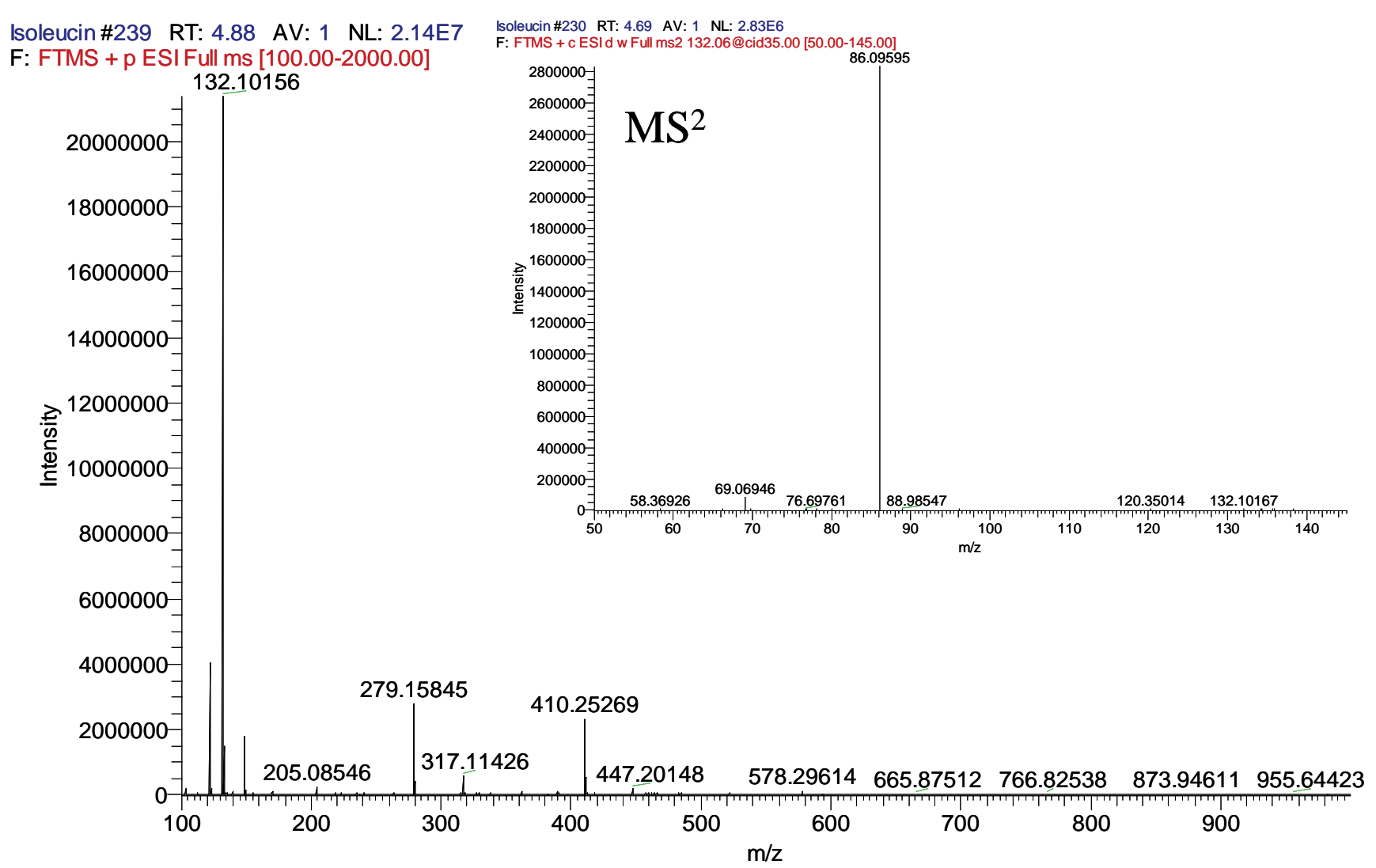

FIGURE A14 | Accurate mass MS and MS2 for isoleucine.

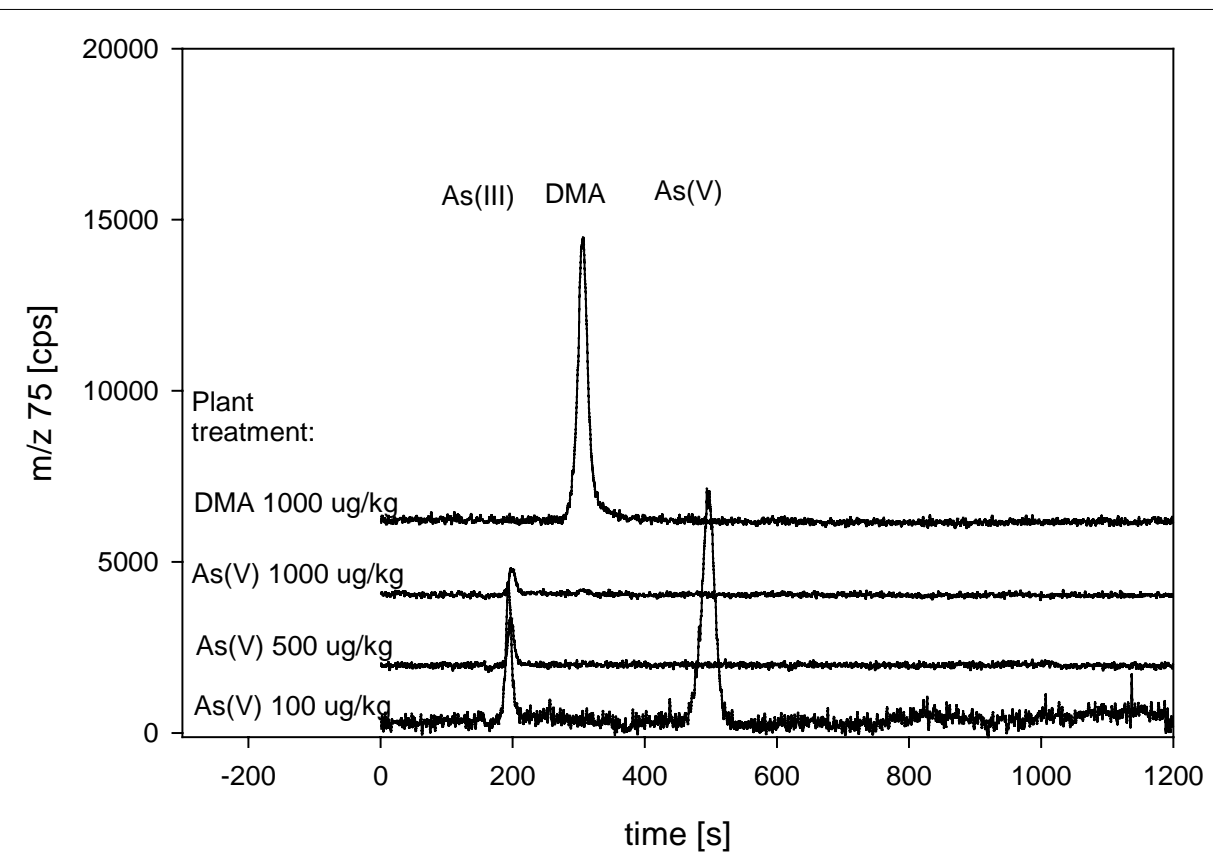

FIGURE A15 | Anion-exchange HPLC-ICP-MS chromatograms of xylem sap samples of plants challenged with $1000 \mu \mathrm{g} / \mathrm{kg}$ DMAV, 100, 500, and $1000 \mu \mathbf{g} / \mathbf{k g ~ A s V}$ for $24 \mathrm{~h}$. Samples of 500 and $1000 \mu \mathrm{g} / \mathrm{kg} \mathrm{As}{ }^{\vee}$ had to be diluted to make up enough sample for injection. All chromatograms have an offset for clarity (Plant set B). 


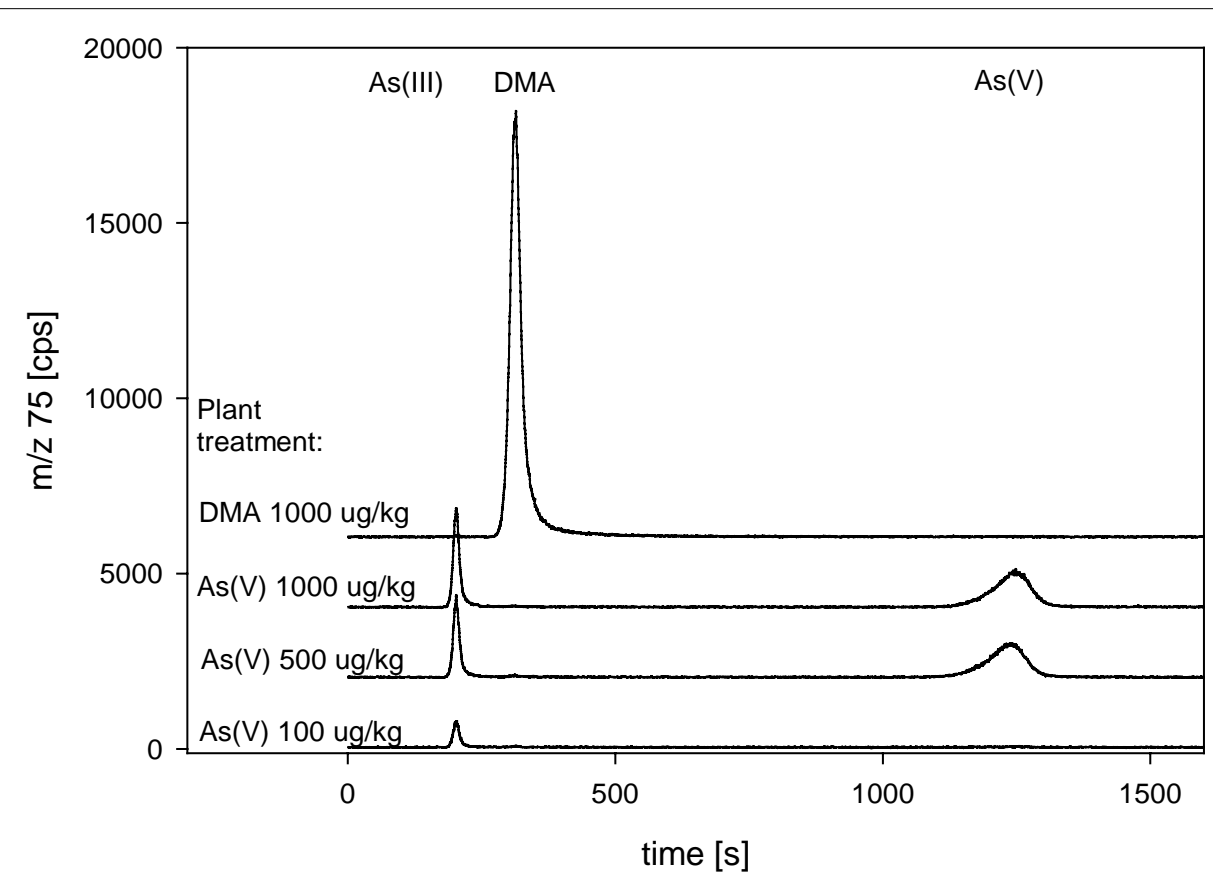

FIGURE A16 | HPLC-ICP-MS chromatograms of xylem sap samples of plants challenged with DMAV $1000 \mu \mathrm{g} / \mathrm{kg}$, AsV 100, 500, and 1000 $\mu \mathrm{g} / \mathrm{kg}$, respectively for $\mathbf{2 4 \mathbf { h }}$. Chromatograms are shifted for clarity (Plant set C).

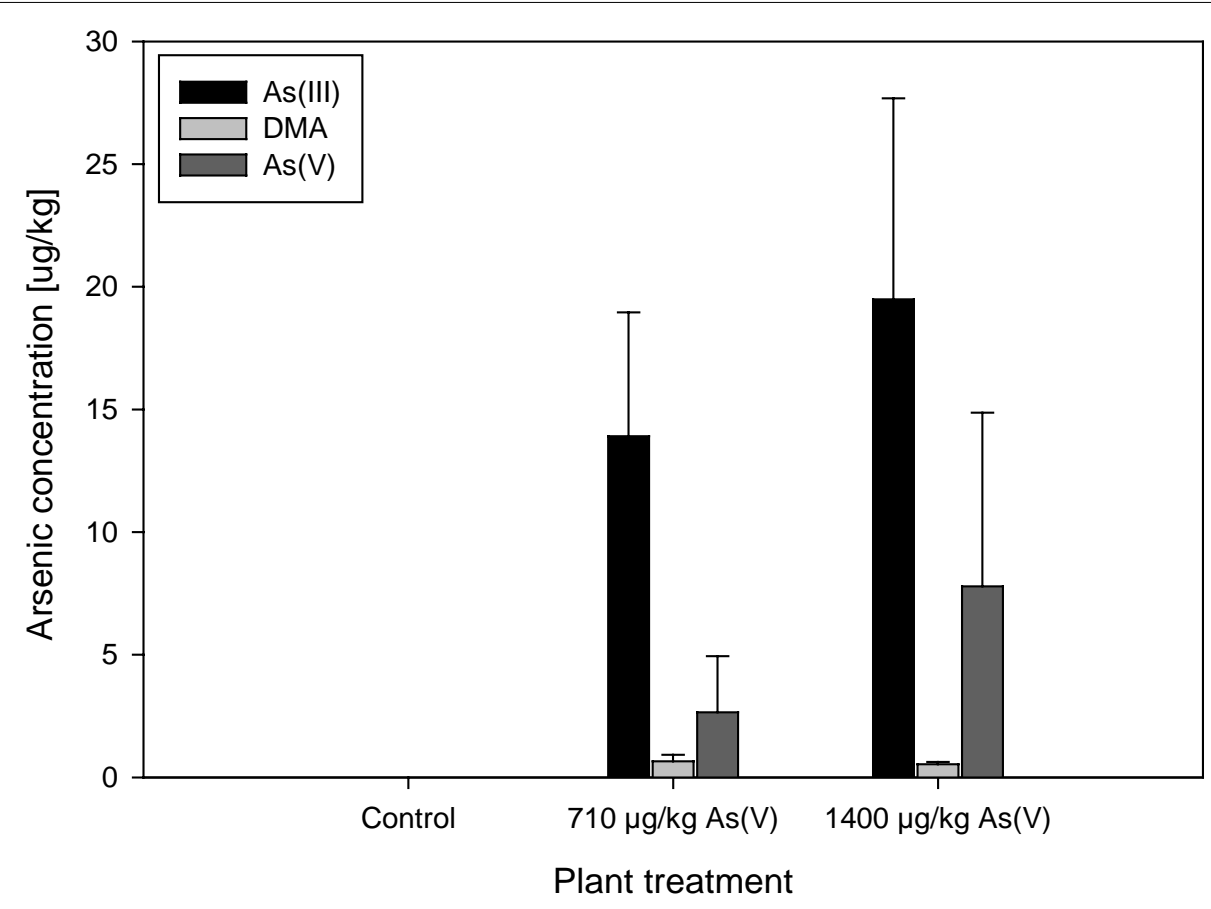

FIGURE A17 | Arsenic concentration and speciation in xylem sap of plants grown for $\mathbf{2 8} \pm \mathbf{3}$ days (plant set A) and challenged with no arsenic and As $(\mathbf{V})$ at $\mathbf{7 1 0}$ and $\mathbf{1 4 0 0} \mu \mathbf{g} / \mathbf{k g}$ for $\mathbf{2 4} \mathbf{~ h}$. Sap extracted for $1 \mathrm{~h}$. Concentration of blank xylem sap was below LOD of $0.5 \mu \mathrm{g} / \mathrm{kg}(3 \sigma$ of noise; $n=12)$. 
Table A1 | Chemical formulae calculated with $\mathrm{m} / \mathrm{z} 132$.

\begin{tabular}{llll}
\hline Index & Formula & RDB & $\Delta$ ppm \\
\hline 1 & $\mathrm{C}_{6} \mathrm{H}_{14} \mathrm{O}_{2} \mathrm{~N}$ & 0.5 & -0.872 \\
\hline
\end{tabular}

Table A2 | Chemical formulae calculated with $\mathrm{m} / \mathrm{z} 203$.

\begin{tabular}{llll}
\hline Index & Formula & RDB & $\Delta$ ppm \\
\hline 1 & $\mathrm{C}_{7} \mathrm{H}_{17} \mathrm{O}_{2} \mathrm{~N}_{5}$ & 2.0 & 3.267 \\
2 & $\mathrm{C}_{9} \mathrm{H}_{19} \mathrm{O}_{3} \mathrm{~N}_{2}$ & 1.5 & -3.342 \\
\hline
\end{tabular}

Table A3 | Chemical formulae calculated with $\mathrm{m} / \mathrm{z} 219$.

\begin{tabular}{llll}
\hline Index & Formula & RDB & \multicolumn{1}{c}{ ppm } \\
\hline 1 & $\mathrm{C}_{7} \mathrm{H}_{9} \mathrm{~N}_{9}$ & 8.0 & -2.113 \\
2 & $\mathrm{C}_{8} \mathrm{H}_{15} \mathrm{O}_{5} \mathrm{~N}_{2}$ & 2.5 & -2.136 \\
3 & $\mathrm{C}_{6} \mathrm{H}_{13} \mathrm{O}_{4} \mathrm{~N}_{5}$ & 3.0 & 3.992 \\
\hline
\end{tabular}

Table A4 | Chemical formulae calculated with $\mathrm{m} / z 253$.

\begin{tabular}{llll}
\hline Index & Formula & RDB & $\Delta$ ppm \\
\hline 1 & $\mathrm{C}_{12} \mathrm{H}_{17} \mathrm{O}_{4} \mathrm{~N}_{2}$ & 5.5 & -1.871 \\
2 & $\mathrm{C}_{10} \mathrm{H}_{15} \mathrm{O}_{3} \mathrm{~N}_{5}$ & 6.0 & 3.434 \\
\hline
\end{tabular}

Table A5 | Chemical formulae calculated with $\mathrm{m} / \mathrm{z} 312$.

\begin{tabular}{llll}
\hline Index & Formula & RDB & $\boldsymbol{\Delta}$ ppm \\
\hline 1 & $\mathrm{C}_{10} \mathrm{H}_{16} \mathrm{O}_{4} \mathrm{~N}_{8}$ & 7.0 & -1.642 \\
2 & $\mathrm{C}_{11} \mathrm{H}_{22} \mathrm{O}_{9} \mathrm{~N}$ & 1.5 & -1.658 \\
3 & $\mathrm{C}_{9} \mathrm{H}_{20} \mathrm{O}_{8} \mathrm{~N}_{4}$ & 2.0 & 2.643 \\
\hline
\end{tabular}

